\title{
Response of South American Terrestrial Ecosystems to Future Patterns of Sea Surface Temperature
}

\author{
Marcos Paulo Santos Pereira, ${ }^{1}$ Marcos Heil Costa, ${ }^{2}$ Flavio Justino, ${ }^{2}$ \\ and Ana Cláudia Mendes Malhado ${ }^{3}$ \\ ${ }^{1}$ Department of Physics, Federal University of Paraná (UFPR), 81531-990 Curitiba, PR, Brazil \\ ${ }^{2}$ Department of Agricultural and Environmental Engineering, Federal University of Viçosa (UFV), Av. P. H. Rolfs, s/n, \\ Campus Universitário, 36570-000 Viçosa, MG, Brazil \\ ${ }^{3}$ Institute of Biological and Health Sciences, Federal University of Alagoas (UFAL), Av. Lourival Melo Mota, $s / n$, \\ Tabuleiro do Martins, 57072-900 Maceió, AL, Brazil \\ Correspondence should be addressed to Marcos Paulo Santos Pereira; marcospspereira@hotmail.com
}

Received 2 December 2016; Revised 20 May 2017; Accepted 31 May 2017; Published 17 July 2017

Academic Editor: Anthony R. Lupo

Copyright (c) 2017 Marcos Paulo Santos Pereira et al. This is an open access article distributed under the Creative Commons Attribution License, which permits unrestricted use, distribution, and reproduction in any medium, provided the original work is properly cited.

\begin{abstract}
Global warming in the first half of the 21st century is likely to have profound influences on South American vegetation and climate. Although coupled atmosphere-biosphere models have been widely used to forecast future vegetation patterns under various scenarios of global warming, they have not been used to assess the potentially critical role of variations in sea surface temperature (SST) in modifying the climate-vegetation interactions. Here, we use monthly output of a 100-year coupled model run to investigate the relationship between SST, precipitation, and productivity of vegetation. Specifically, we assess statistical correlations between SST variability and vegetation in six different South America regions: Northern South America, Western Amazonia, Eastern Amazonia, Northeast Brazil, Central Brazil, and Patagonia. Our model robustly simulates changes in mean precipitation, net primary production (NPP), upper canopy leaf area index (LAI), and lower canopy LAI under warming and nonwarming scenarios. Most significantly, we demonstrate that spatial-temporal variability in SST exerts a strong influence over the vegetation dynamics in all six South American regions.
\end{abstract}

\section{Introduction}

Global warming will have dramatic impacts on ecosystems and the species that inhabit them (e.g., [1]), and it is vitally important that scientists are able to develop robust models that realistically capture the complex and dynamic relationship between the climate and vegetation [2]. The response of South American vegetation to climate change may be particularly important, since this continent still contains the largest (but rapidly diminishing) continuous area of tropical rainforest [3]. There are several models that simulate the dynamic relationship between climate and vegetation at a macrogeographic scale [4-9]. These could be of great utility for climate modelers since, unlike many climate simulations, they consider the atmosphere and terrestrial biosphere as a coupled system with biogeophysical and biogeochemical processes occurring across a range of timescales [10]. Specifically, when a dynamic model is coupled to an atmospheric general circulation model, it is possible to investigate the influence of vegetation dynamics on climate change under conditions of global warming [7].

Previous studies using coupled atmosphere-biosphere models indicate that the Amazon region will suffer a significant decline in rainfall, leading to the rapid loss of rainforest and, consequently, a further decrease in rainfall $[5,6,11]$. However, these results are strongly in contrast to the results from the modeling studies on the response of tropical vegetation to elevated $\mathrm{CO}_{2}$ [12]. Some simulations indicate that the increase in $\mathrm{CO}_{2}$ will be accompanied by an increase in vegetation cover: this process would initiate a 
feedback loop in the hydrological cycle, leading to increases in precipitation and soil moisture [4].

Conflicting model results such as those described above may be due, in part, to the influence of sea surface temperature (SST). The South American climate is strongly dependent on the patterns of SST in the Pacific and Atlantic [13-16] and any changes in climate will have knock-on effects on vegetation. For example, when a global scale coupled climate-vegetation model was forced by future SST and sea ice (projected with 17 atmosphere-ocean general circulation models participating in the IPCC Fourth Assessment Report and by appropriate atmospheric carbon dioxide concentrations under the A2 emission scenario [17]), vegetation was predicted to become denser as mean global leaf area index (LAI) increases.

Although several studies using coupled models have already investigated the effects of vegetation feedback under global warming $[4-6,11]$, they either are restricted to particular parts of South America such as the Amazon or do not take into account the behavior of vegetation in relation to SST variability. Simulations of the Amazon rainforest for 20112050 show that certain patterns of SST are likely to decrease the extent of tropical evergreen rainforest and savanna: these areas will be occupied mainly by tropical deciduous rainforest, emitting an average of $0.53 \mathrm{Pg}-\mathrm{C} \cdot \mathrm{yr}^{-1}$ during the transition [18].

The objective of this study is therefore to evaluate the effect of spatial-temporal variability of SST on South American vegetation dynamics under global warming, using a coupled climate-vegetation model. Specifically, the study seeks to answer the following questions:

(i) How will the vegetation of South America respond to future patterns of SST in the Pacific and Atlantic?

(ii) What correlations exist between the SST variability and vegetation characteristics in different South America regions?

The paper is organized as follows. First, we provide a concise overview of the model, including processing schemes, details of the initial state spin-up, simulation setting, and forcing data. Second, we analyze the simulation results and discuss the accuracy of the model simulation, the predicted response of South American terrestrial ecosystems to global warming in first half of 21st century, and the influence of ocean surface patterns in the South America ecosystem variables. Finally, we discuss the efficacy and validity of the study.

\section{Model Description and Experiment Design}

Experiments were performed with the National Center for Atmospheric Research (NCAR) Community Climate Model Version 3 (CCM3) [19] with spatial resolution T42 $\left(2.81^{\circ} \times\right.$ $\left.2.81^{\circ}\right), 18$ vertical levels in the atmosphere, and using a hybrid sigma-pressure coordinate system and a time step interval of 15 minutes. The version of the model used in this paper used the convection schemes of Zhang and McFarlane [20] and Hack [21] which reduces the overall magnitude of the hydrologic cycle and becomes especially important in the simulation of tropical precipitation. The oceans are represented by monthly averaged fixed sea surface temperatures and serve as boundary conditions for the atmosphere.

This model is coupled with an updated version of the surface model known as the Integrated Biosphere Simulator (IBIS) [22]. IBIS is a dynamic global vegetation model which simulates changes in the composition and structure of vegetation in response to environmental conditions (detailed specification in [23]).

IBIS provides a representation of vegetation dynamics appropriate for global ecosystem modeling. The net primary production (NPP) is calculated by integrating primary production through the year discounting maintenance respiration and the carbon lost due to growth respiration. Leaf area index (LAI) is simulated according to climatic conditions such as temperature, precipitation, and plant productivity, which in turn depend on LAI. In each grid cell of the model, a number of plant functional types (PFTs) can exist simultaneously. Competition among PFTs is characterized by the ability of plants to capture common resources (light and water). For example, light is first captured by the leaves of PFTs in the upper canopy (trees) and therefore less light is available to the lower canopy (grasses). However, the roots of lower canopy plants have primary access to moisture as they infiltrate through the soil [22]. Competition between PFTs in the same layer of the canopy is represented as differences in annual carbon balance resulting from different ecological strategies [24].

The coupled CCM3-IBIS model is used to reproduce the bidirectional interactions between land surface and the atmosphere, important for the study of biome distribution, ecosystem function, and climate feedbacks in the context of both global climate change and land use change [10]. CCM3-IBIS was calibrated against Large Scale Biosphere-Atmosphere Experiment in Amazonia (LBA) tower results and extensively validated against spatial fields of incident solar radiation, precipitation, land cover patterns, heterotrophic and root respiration, total NPP, aboveground NPP, wood NPP, leaf area index, and aboveground live biomass [25]. The simulated climatological precipitation of the CCM3-IBIS model is well correlated with the observed dataset in regions of South America [26, 27].

Two groups of simulations were conducted: (1) a control simulation for the second half of the 20th century which assumes present-day conditions and (2) a series of ten experimental simulations for future climate scenarios for the first half of the 21st century. Each simulation ran for 50 years, with three repetitions (ensembles) per group of simulations.

The control simulation uses observational data from global SST (https://www.cdc.noaa.gov/data/gridded/data .noaa.oisst.v2.htm) and atmospheric $\mathrm{CO}_{2}$ concentration (https://www.esrl.noaa.gov/gmd/ccgg/trends/) for the period from 1951 to 2000. To obtain a more realistic representation of vegetation and climate scenarios for the same time period, the control simulation used three ensembles with different dates for initial condition.

The series of ten experimental simulations use data from global SST obtained from PCMDI (Program for Climate Model Diagnosis and Intercomparison). Ten representative coupled climate models are chosen (out of those used by the 
TABLE 1: CMIP3 climate model, resolution, and main references.

\begin{tabular}{lccc}
\hline Model & Atmosphere & Resolution & References \\
\hline CCCMA CGM 3.1 (T47) & T47 $(3.75 \times 3.75)$, L31 & $1.85 \times 1.85$, L29 & {$[40]$} \\
CNRM CM3 & T63 $(2.8 \times 2.8)$, L45 & $1.875 \times(0.5-2)$, L31 & {$[41]$} \\
CSIRO MK 3.0 & T63, L18 & $1.875 \times 0.84$, L31 & {$[42]$} \\
GFDL CM 2.1 & $2.5 \times 2.0$, L24 & $1.0 \times(1 / 3-1)$, L50 & {$[43]$} \\
GISS MODEL E_R & $5 \times 4$, L20 & $5 \times 4$, L13 & {$[44]$} \\
IPSL CM 3.0 & $2.5 \times 3.75$, L19 & $2 \times(1-2)$, L30 & {$[45]$} \\
MIROC 3.2 MEDRES & T42, L20 & $1.4 \times(0.5-1.4)$, L43 & {$[46]$} \\
MPI ECHAM5 & T63, L32 & $1 \times 1, \mathrm{~L} 41$ & {$[47]$} \\
NCAR CCSM 3.0 & T85L261.4 1.4 & $1 \times(0.27-1), \mathrm{L} 40$ & {$[48]$} \\
UKMO HADCM3 & $3.75 \times 2.5, \mathrm{~L} 19$ & $1.25 \times 1.25, \mathrm{~L} 20$ & {$[49]$} \\
\hline
\end{tabular}

IPCC in AR4) on the basis of spatial resolution and include a representative sample of meteorological research centers (see Table 1 for models, resolution, and references). All simulations have atmospheric concentrations of $\mathrm{CO}_{2}$ and $\mathrm{CH}_{4}$ in accordance with the IPCC A2 scenario. Three ensembles are conducted for all simulations, with runs starting on 17-19 January 2001. The total experiment includes 1,650 years of simulation: $(3$ ensembles $\times 50$ years $\times 1$ SST $)+(1$ scenario $\times$ 3 ensembles $\times 50$ years $\times 10$ SST).

We also run the same experiment using the IPCC B1 scenario; however, since the results are qualitatively identical (and for conciseness), we present only results for the A2 scenario.

The performance of the CCM3-IBIS model in simulating the regional climate during the 1971-2000 period in South America is verified by a comparison of the simulated precipitation against six different precipitation databases. These databases include two climatological surface rain gauge datasets (Climatic Research Unit (CRU [28]) and Willmott and Matsuura [29]), two that blend remote sensing data with surface rain gauges (Climate Prediction Center (CPC) Merged Analysis of Precipitation (CMAP [30]) and Global Precipitation Climatology Project (GPCP [31])), and two reanalysis datasets (National Centers for Environmental Prediction (NCEP)-NCAR [32] and the 40-year European Centre for Medium-Range Weather Forecasts (ECMWF) Reanalysis (ERA-40) [33]).

The study is conducted on six different climate regions over South America: Northern South America (NSA), with coordinates on land of $0^{\circ}$ to $10^{\circ} \mathrm{N}$ by $60^{\circ} \mathrm{W}$ to $77^{\circ} \mathrm{W}$; Western Amazonia (WA) within $2^{\circ} \mathrm{N}$ to $9^{\circ} \mathrm{S}$ and $63^{\circ} \mathrm{W}$ to $80^{\circ} \mathrm{W}$; Eastern Amazonia (EA) within $2^{\circ} \mathrm{N}$ to $9^{\circ} \mathrm{S}$ and $49^{\circ} \mathrm{W}$ to $62^{\circ} \mathrm{W}$; Northeast Brazil (NEB) within $2^{\circ} \mathrm{S}$ to $18^{\circ} \mathrm{S}$ and $36^{\circ} \mathrm{W}$ to $48^{\circ} \mathrm{W}$; Central Brazil (CB) within $10^{\circ} \mathrm{S}$ to $26^{\circ} \mathrm{S}$ and $49^{\circ} \mathrm{W}$ to $62^{\circ} \mathrm{W}$; and Patagonia (PA) within $28^{\circ} \mathrm{S}$ to $49^{\circ} \mathrm{S}$ and $56^{\circ} \mathrm{W}$ to $68^{\circ} \mathrm{W}$ (Figure 1). We remove the global warming trend, based on calculating the average linear regression, to show SST isolated effect over vegetation and precipitation patterns of South America without influence of greenhouse gases.

\section{Results and Discussion}

3.1. Validation of Model Performance. There is high regional variability in the seasonal precipitation cycle in South America (see grid cells indicated in Figure 1). Specifically, NSA, WA, and EA regions show high precipitation, while NEB, CB, and PA regions have lower values. Simulated precipitation is within the amplitude of the datasets, and seasonality is also well simulated with a delayed rainy season in the NSA and WA, which have no impact on the analysis of the results performed here. The simulated precipitation for the Amazon tropical evergreen forest region has been described in detail in a previous study [26] which found that annual mean precipitation was within $10 \%$ of the precipitation mean of five datasets and that seasonality was also well simulated. The performance of the CCM3-IBIS model in simulating the interannual variability for the NEB has been documented in Pereira et al. [27] who report a very good agreement between the datasets but smaller amplitude variations.

3.2. Comparison of Present-Day/Future Climate and Vegetation. Climate conditions in South America simulated by CCM3-IBIS model for 2041-2050 in response to increased greenhouse gases differ from the baseline (1991-2000) climate (Figure 2). There is a mean decadal precipitation increase in the WA region and decrease in the NSA region (Figures $2(a)-2(c))$. These differences in precipitation are characteristic of South America precipitation anomalies during El Niño events [34]. The future scenario (2041-2050) shows an increase in NPP across almost all areas of South America due to elevated atmospheric $\mathrm{CO}_{2}$-the $\mathrm{CO}_{2}$ fertilization effect. The vegetation becomes more productive over WA (Figures $2(\mathrm{~d})-2(\mathrm{f})$ ), mainly due to regional precipitation increases. Higher NPP leads to an increase in the upper canopy LAI in all areas of South America, except NSA (Figures 2(g)-2(i)). Lower canopy LAI increases over the PA region, where grassland vegetation predominates. In contrast to upper canopy LAI, anomalies in lower canopy LAI show positive trends over the NSA region and negative trends in the NEB region (Figures $2(\mathrm{j})-2(\mathrm{l})$ ). 


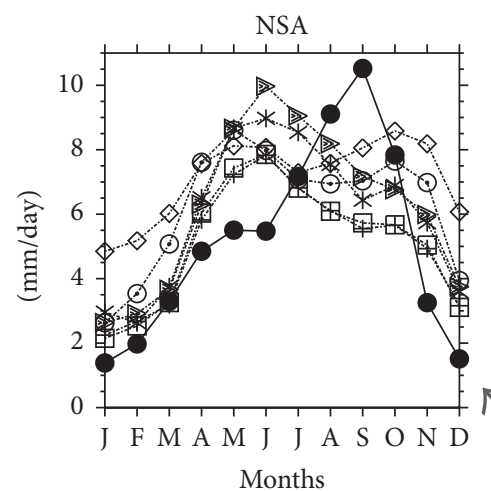

(a)
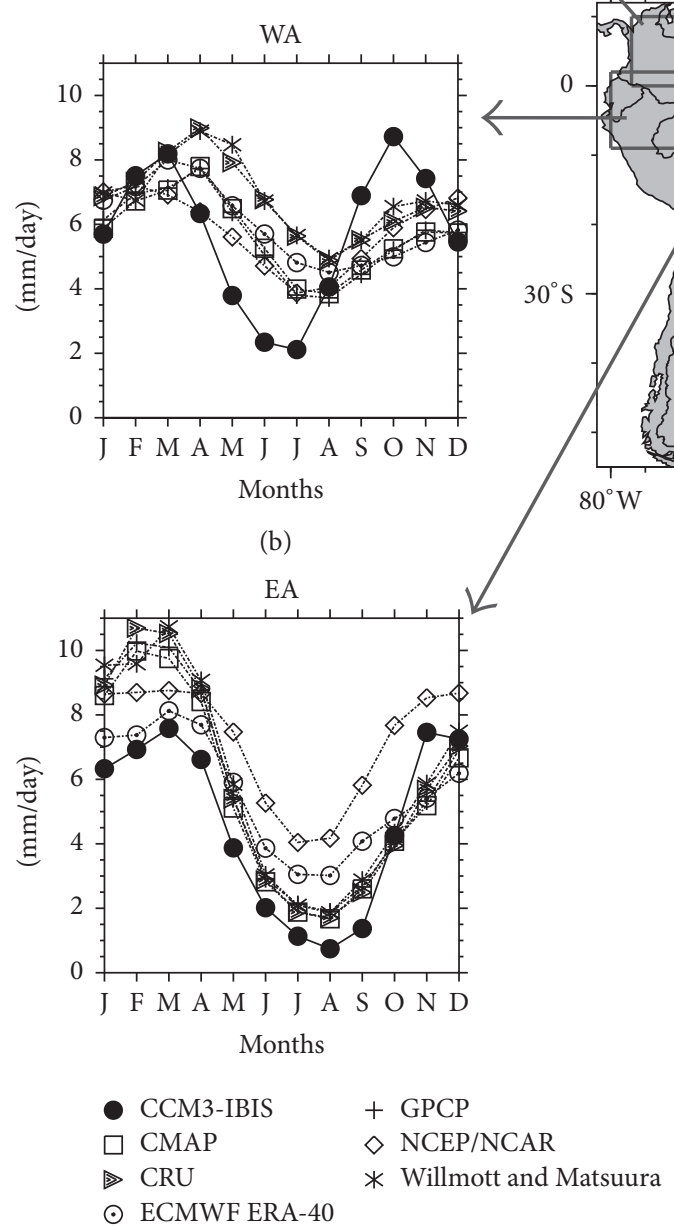

(c)

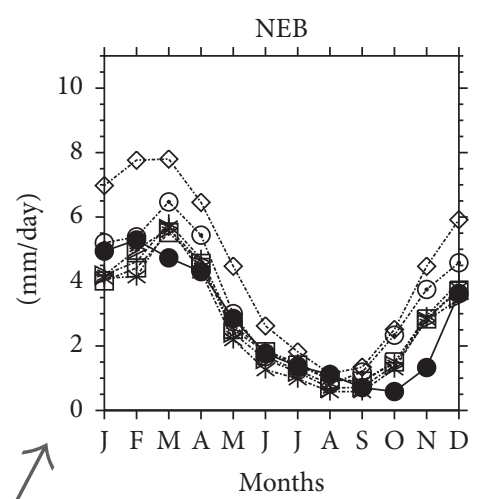

(d)

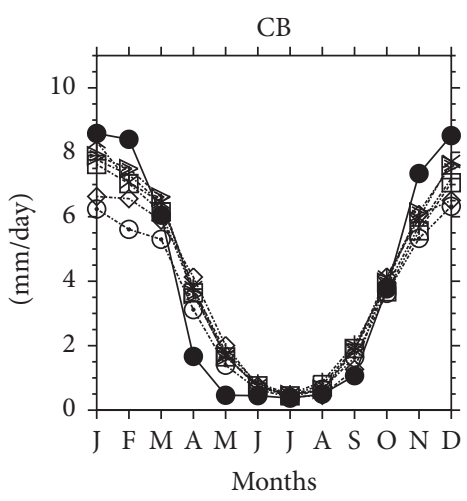

(e)

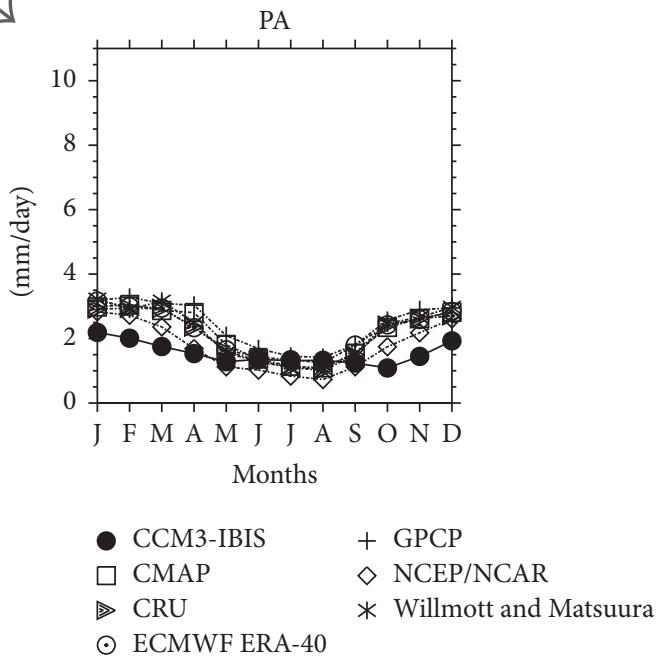

(f)

Figure 1: Seasonal cycle of precipitation climatology for the North of South America (a), West Amazonia (b), East Amazonia (c), Northeast Brazil (d), Central Brazil (e), and Patagonia (f). Individual data sources (various markers; see legend). Boxes indicate the regions as defined for this analysis in the period of 1971-2000.

The coefficient of variation (the ratio of the standard deviation to the mean as a measure of relative variability) was used to compare the decadal variability of present-day conditions (1991-2000) and the future simulations (2041-2050) in the context of mean precipitation, NPP, upper canopy LAI, and lower canopy LAI (Figure 3 ). The largest coefficient of variation is found in the future scenario, which is also characterized by a large standard deviation. This increase is attributable to the variability in the ten future patterns of SST (an analysis of 300 years ( 3 ensembles $\times 10$ years $\times 10$ SSTs)). GCMs disagree on the future projected SST patterns in the Tropics, even if run under the same $\mathrm{CO}_{2}$ 


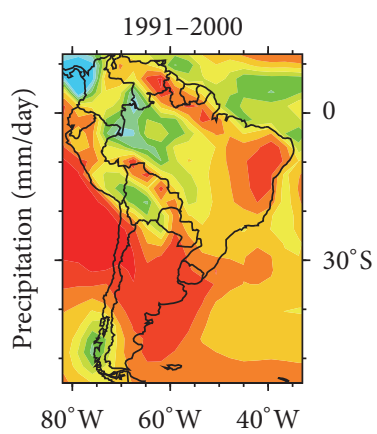

(a)

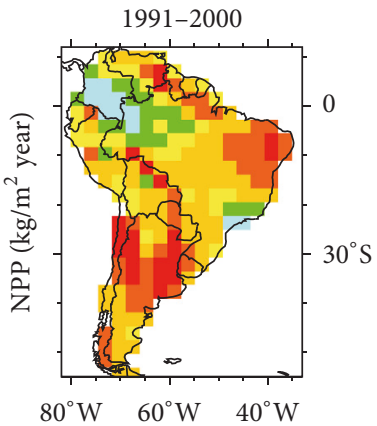

(d)

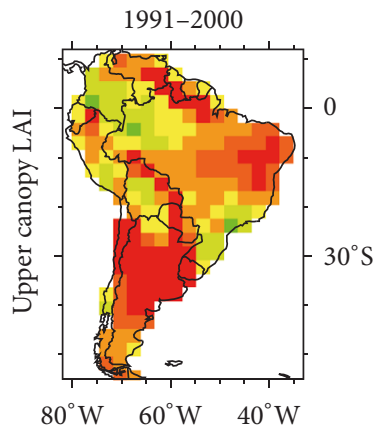

(g)

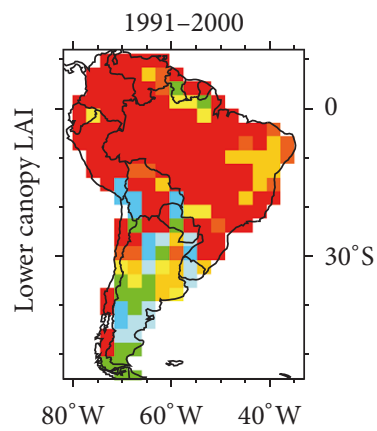

(j)

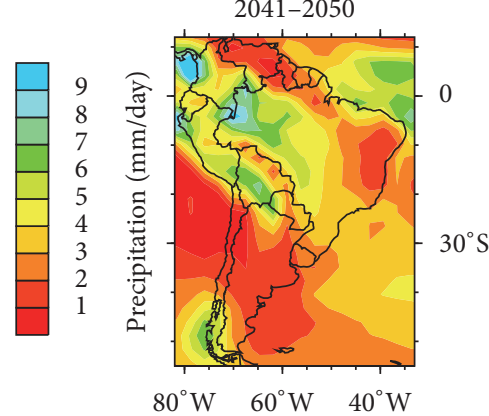

(b)

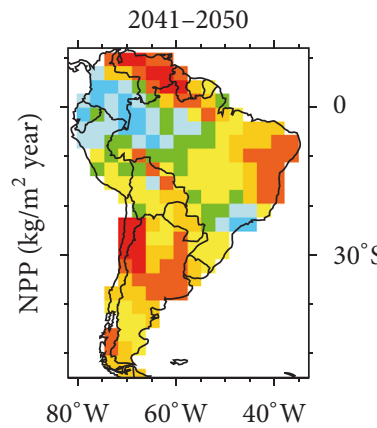

(e)

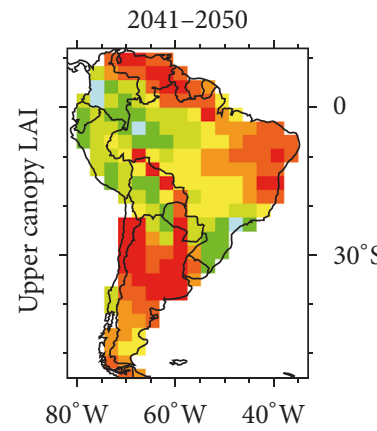

(h)

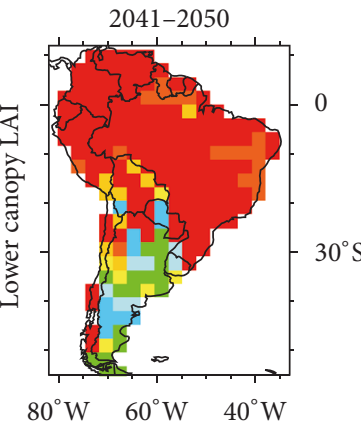

$(\mathrm{k})$

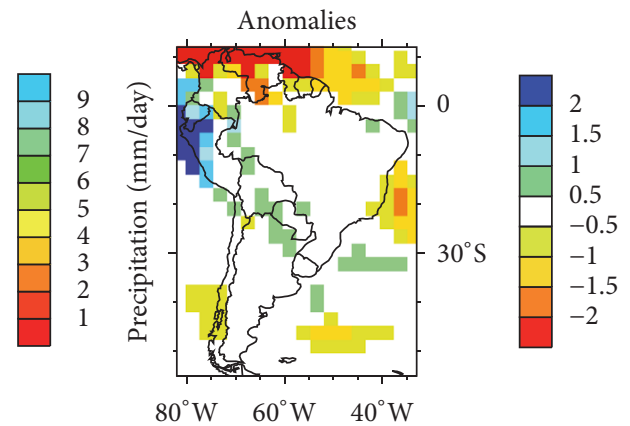

(c)

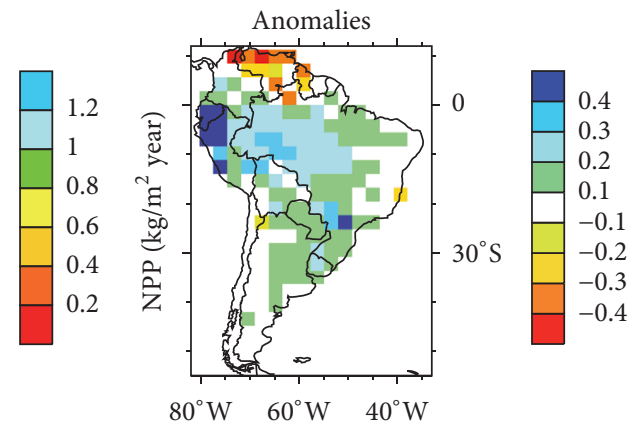

(f)

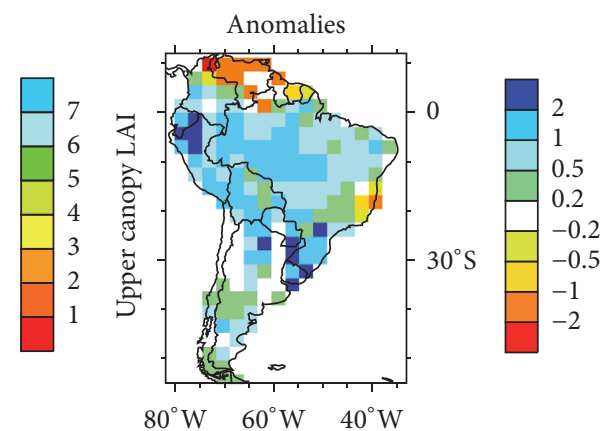

(i)

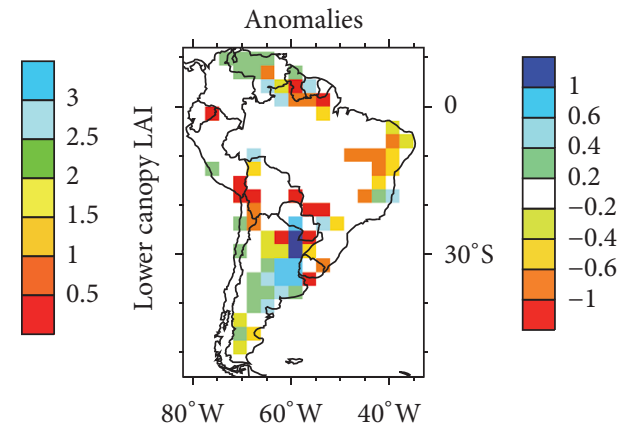

(l)

Figure 2: Decadal means of precipitation (mm/day) (a-b), NPP (kg C/m $\mathrm{m}^{2}$ year) (d-e), upper canopy LAI ( $\left.\mathrm{m}^{2} / \mathrm{m}^{2}\right)(\mathrm{g}-\mathrm{h})$, and lower canopy LAI $\left(\mathrm{m}^{2} / \mathrm{m}^{2}\right)(\mathrm{j}-\mathrm{k})$ in South America over present-day conditions (1991-2000) (a, d, g, j) and future scenario (2041-2050) (b, e, h, k) and anomalies (2041-2050; 1991-2000) (c, f, i, l). 


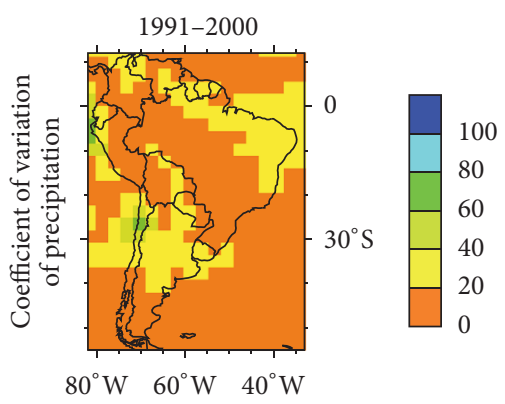

(a)

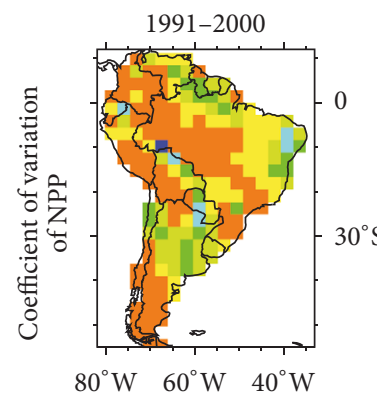

(d)

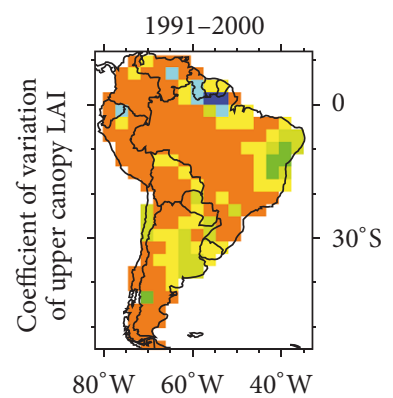

(g)

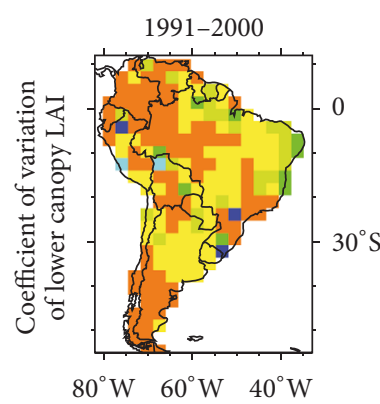

(j)

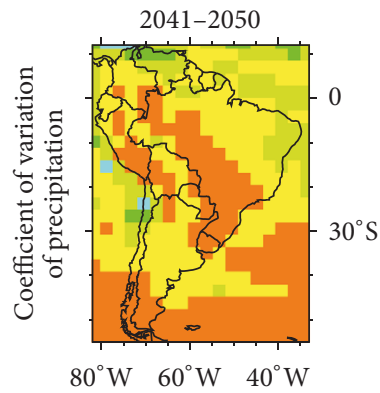

(b)

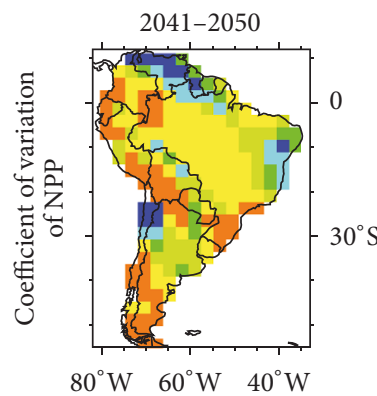

(e)

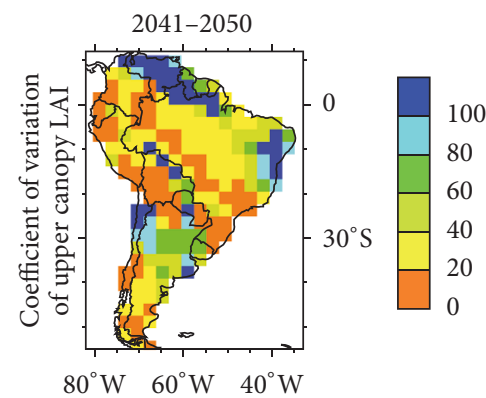

(h)

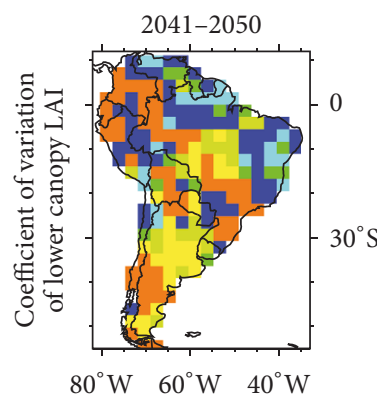

(k)

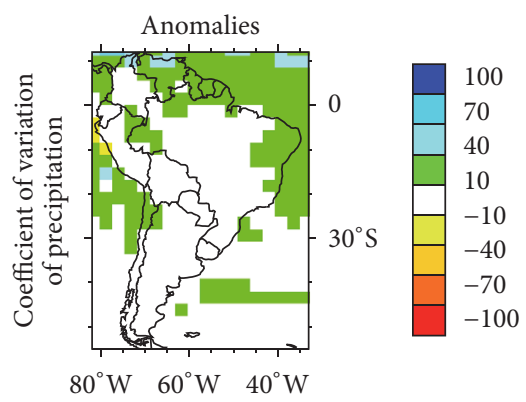

(c)

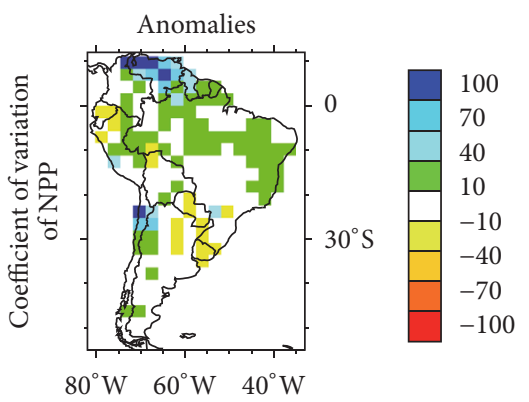

(f)

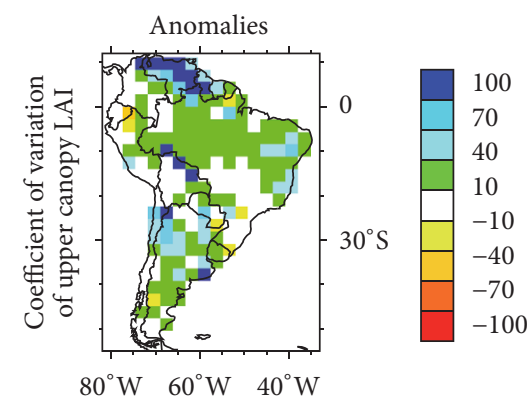

(i)

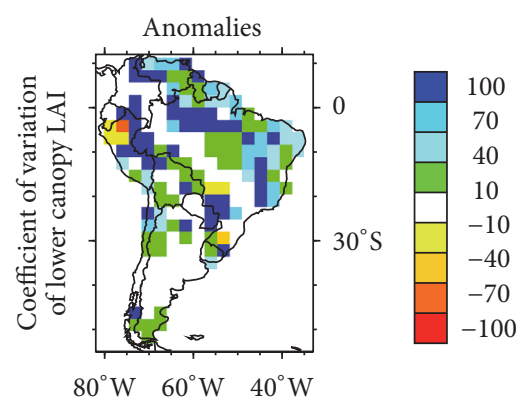

(1)

Figure 3: Coefficients of variation of precipitation (a-b), the NPP (d-e), upper canopy LAI ( $\mathrm{g}$-h), and lower canopy LAI (j-k) in South America over present-day conditions (1991-2000) (a, d, g, j) and future scenario (2041-2050) (b, e, h, k) and anomalies (2041-2050; 1991-2000) (c, f, i, l).

concentration scenario [35]. In contrast, the simulation of present-day conditions only consists of an analysis of 30 years ( 3 ensembles $\times 10$ years $\times 1$ SST). Nevertheless, the coefficient of variation is probably underestimated due to the use of a single model.

Changes in vegetation cover between 1991 and 2000 and between 2041 and 2050 are also observed (Figure 4). One of the clearest changes is the replacement of savanna by tropical deciduous forest. However, the distributions of the other major South American biomes do not change significantly in the experimental simulations. Jiang et al. [17] examined the vegetation feedback under future global warming using an asynchronously coupled system between the atmospheric model and the biosphere model, forced by monthly SST and 


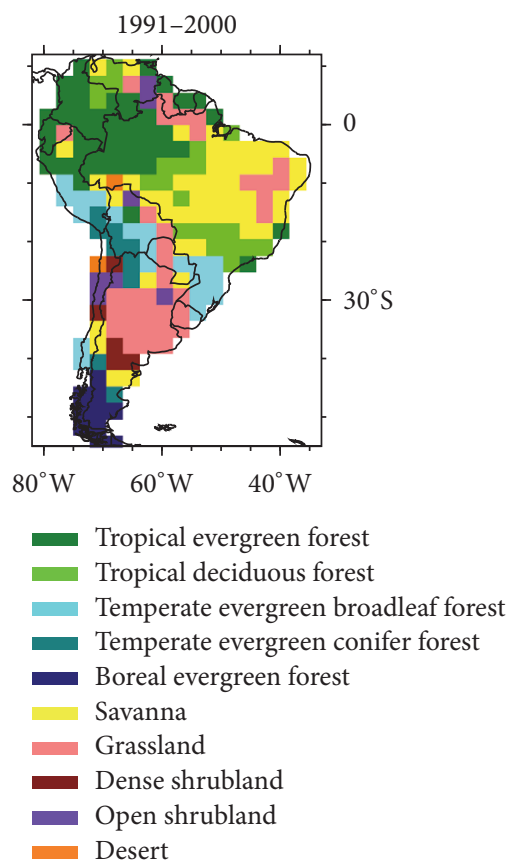

(a)

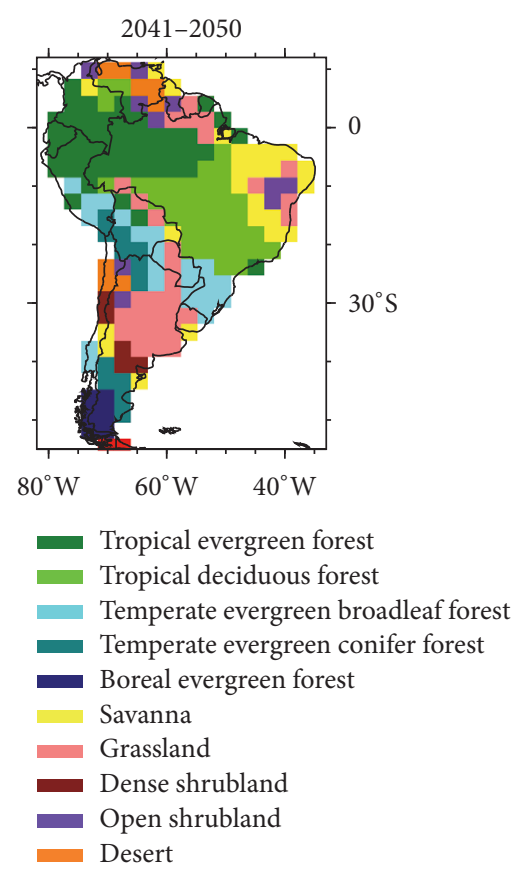

(b)

FIGURE 4: Vegetation cover in South America over (a) present-day conditions (1991-2000) and (b) future scenario (2041-2050).

sea ice extent datasets as simulated by IPCC AR4. For the period of 2051-2060, they also have found an increase of the deciduous forest under same region of our experiment.

3.3. Correlations between SST Variability and Vegetation. The influence of spatial variation in SST is based on a series of bidimensional correlations between the 10 future patterns of SST and precipitation data, NPP, upper canopy LAI, and lower canopy LAI-estimated from the different SST scenarios for 2011-2050. These data are analyzed for 400 years (40 years $\times 10$ SST scenarios) for all six regions (Figures 5-10). The correlation between the mean spatial variation for each region and SST for each point on the grid is assessed under the influence of global warming scenarios (Figures 5(a)-5(d) and $10(\mathrm{a})-10(\mathrm{~d}))$ and with the warming trend removed (Figures 5(e)-5(h) and 10(e)-10(h))

Precipitation, NPP, and upper canopy LAI over the NSA region are negatively correlated with SST in the equatorial Pacific and Atlantic oceans (Figures 5(a)-5(c)). The Northern Hemisphere plays an important role in inducing positive precipitation anomalies in the tropical and subtropical Atlantic (cf. [36]). Increases in SST over this region induce a northward position of the Intertropical Convergence Zone (ITCZ) associated with changes in the meridional gradient of atmospheric pressure in the tropical Atlantic [37] leading to increased precipitation in the NSA. Statistically significant correlations are also generated in the western Pacific, along the coast of Japan, and near the west coast of South America. This pattern is very similar to the warm phase of the Pacific Decadal Oscillation (PDO) [38]. However, the correlation between lower canopy LAI and SST is positive in the equatorial region of both Atlantic and Pacific oceans and negative elsewhere, which may resemble the cool phase of the PDO (Figure 5(d)).

When global warming is removed, the largest correlation between precipitation and SST is over the NSA. Thus, La Niña years induce positive precipitation anomalies (Figure 5(e)). This is partially reproduced by the NPP (Figure 5(f)), although changes in NPP and upper canopy LAI (Figure 5(g)) are also influenced by the warmer subtropical Pacific. Lower canopy LAI is more highly correlated with the colder equatorial Pacific as indicated by the precipitation anomalies (Figures 5(h) and 5(e)).

There is a positive correlation between precipitation, NPP, and upper canopy LAI in the WA region and SSTs in large parts of the Pacific and Atlantic oceans (Figures 6(a)-6(c)). This indicates that there is no substantial dependence of the WA climate-vegetation patterns on the equatorial Pacific climate variability under global warming (i.e., the global effect of higher SST is dominant). However, in the case of lower canopy LAI, equatorial SSTs may play a role in defining the pattern of change (Figure $6(\mathrm{~d})$ ). These results differ from those predicted for the NSA region. In the absence of global warming, the equatorial Pacific is highly correlated with the WA region for both precipitation and NPP but does not strongly affect upper canopy LAI, which exhibits a higher correlation with Southern Hemisphere SSTs (Figures 6(e)-6(g)). The WA region is statistically correlated with the subtropical Atlantic ocean, perhaps due to the influence of the South Atlantic Convergence Zone (SACZ). However, there is no statistically significant correlation for lower canopy LAI (Figure 6(h)).

SST is correlated with precipitation, NPP, and upper canopy LAI in the EA region under global warming and 


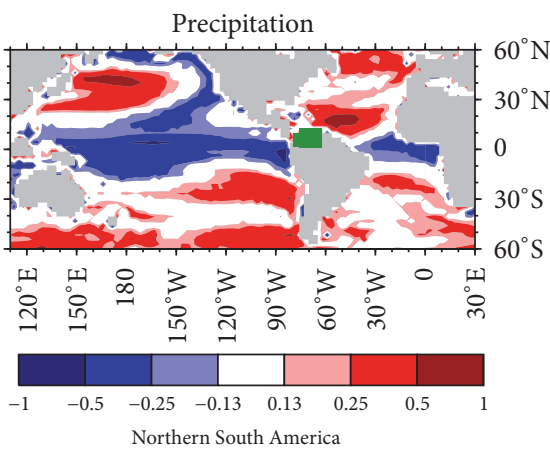

(a)

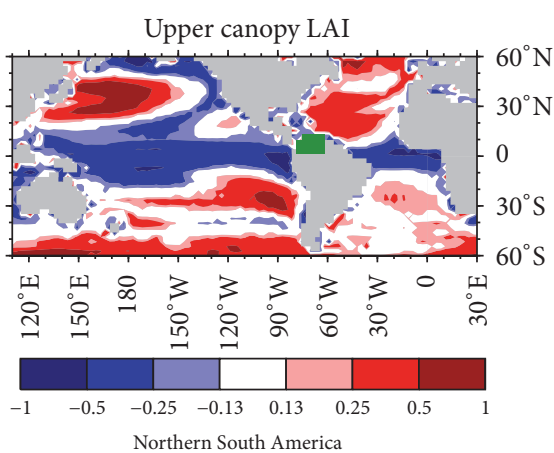

(c)

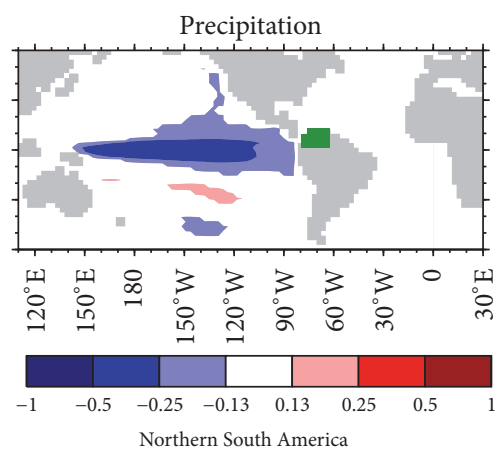

(e)

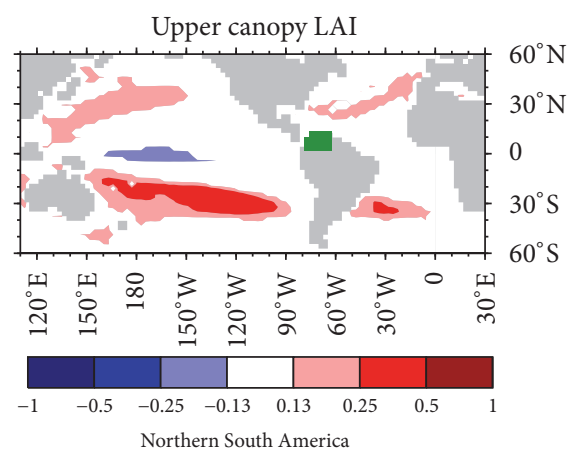

(g)

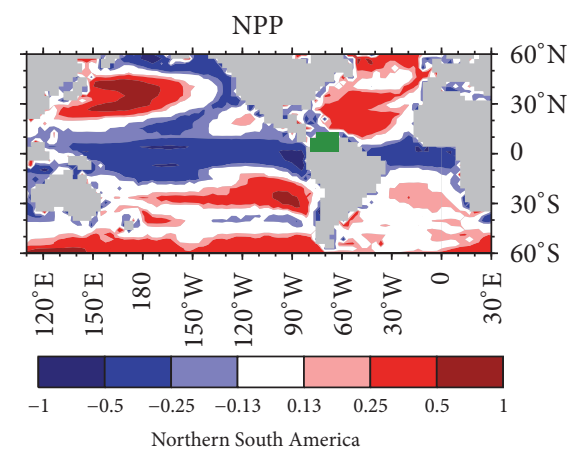

(b)

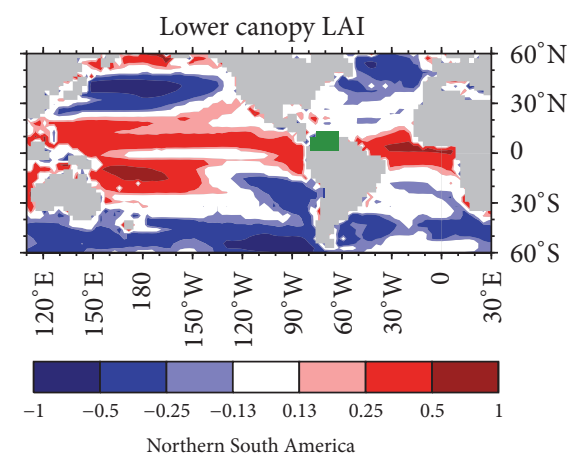

(d)

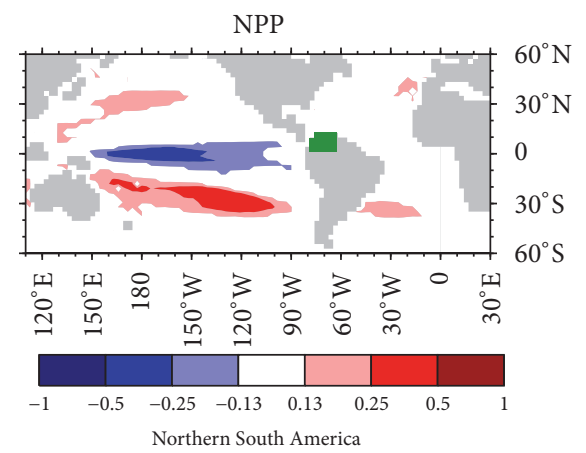

(f)

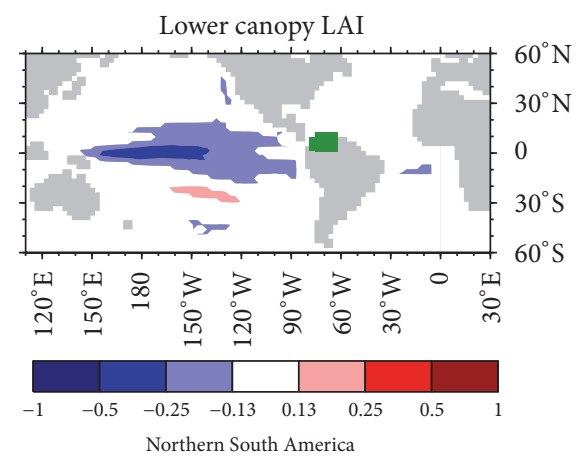

(h)

Figure 5: Panels (a-h) illustrate the correlation coefficients between SST and climate and vegetation patterns in NSA 2011-2050, where panels $(\mathrm{a}-\mathrm{d})$ are based on increased $\mathrm{CO}_{2}$ atmospheric concentration for the A2 scenario of IPCC and panels (e-h) illustrate the results without the trend of global warming (see text for details). It should be noted that these figures only show significant values at the 0.01 level of a Student's $t$-test with a positive or negative correlation of greater than 0.13 . 


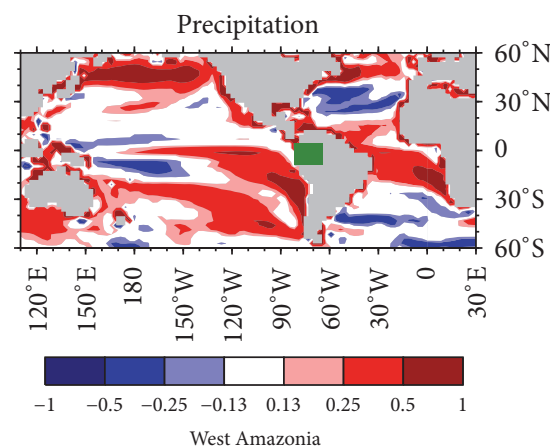

(a)

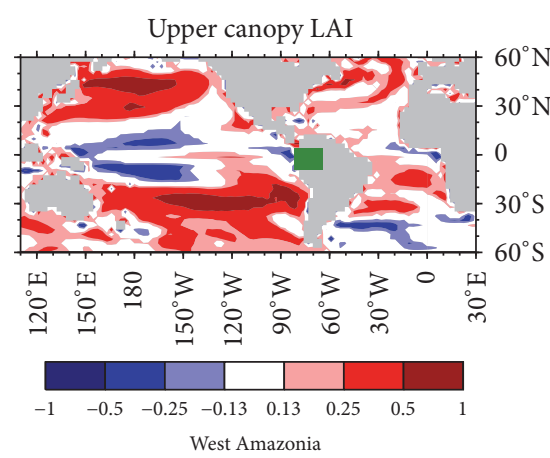

(c)

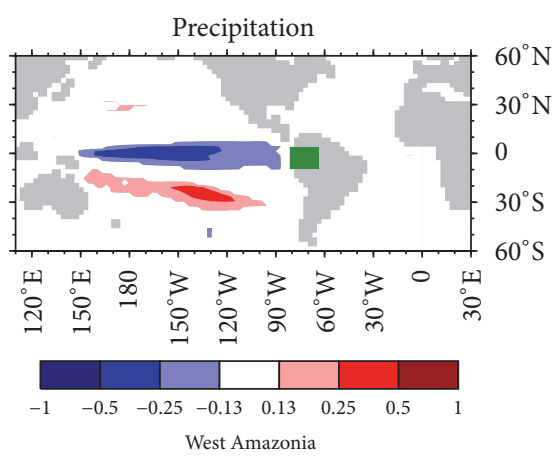

(e)

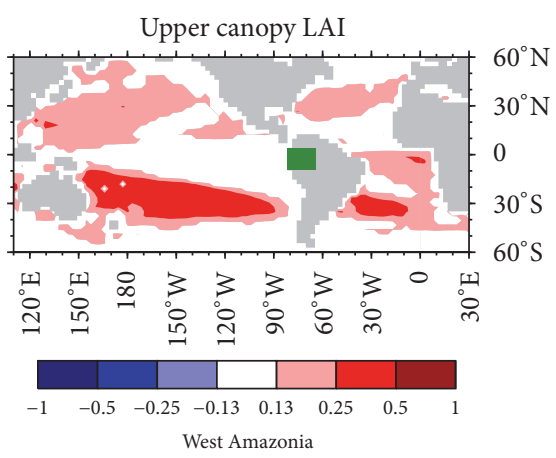

(g)

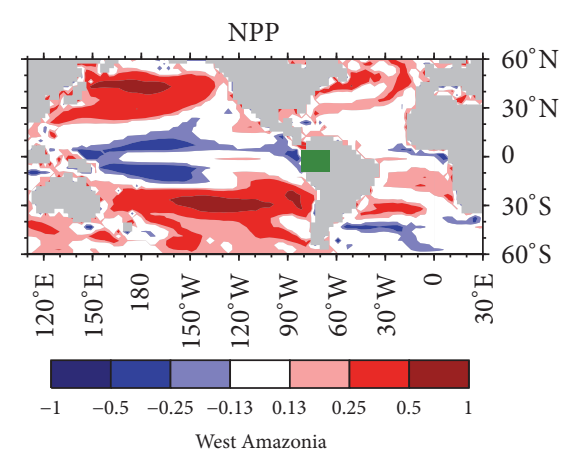

(b)

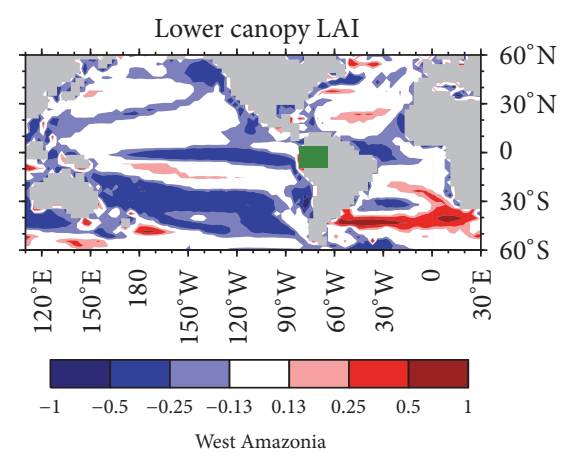

(d)

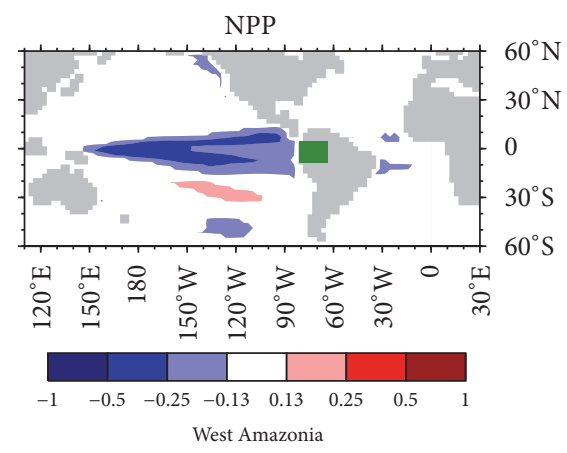

(f)

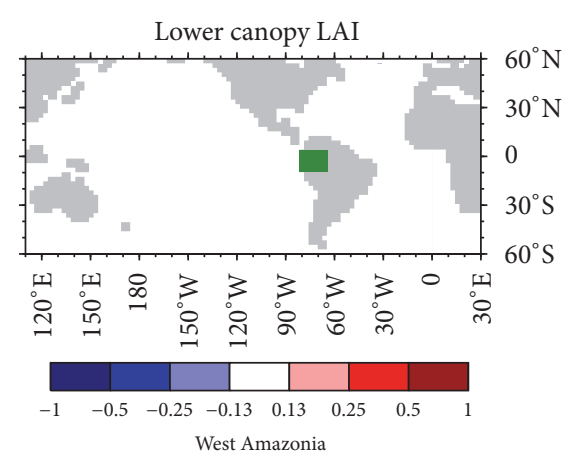

(h)

FIgURE 6: Same as Figure 5 but for WA region. 


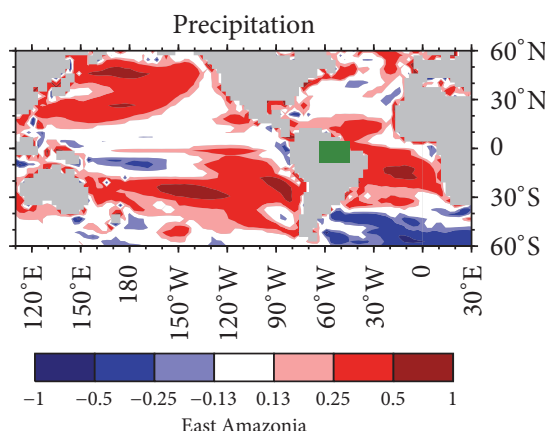

(a)

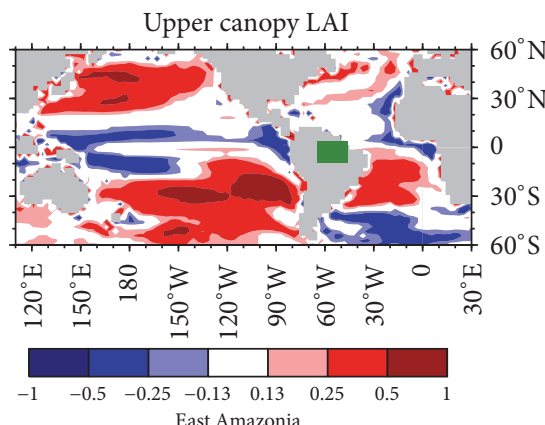

(c)

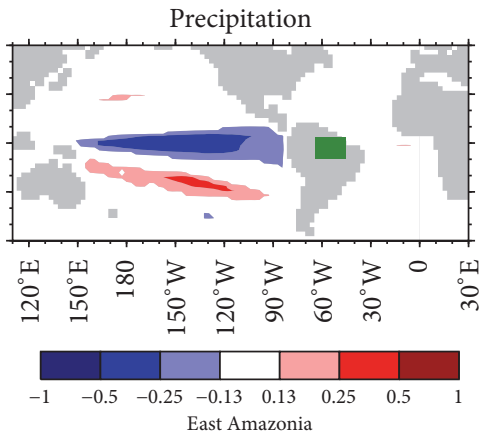

(e)

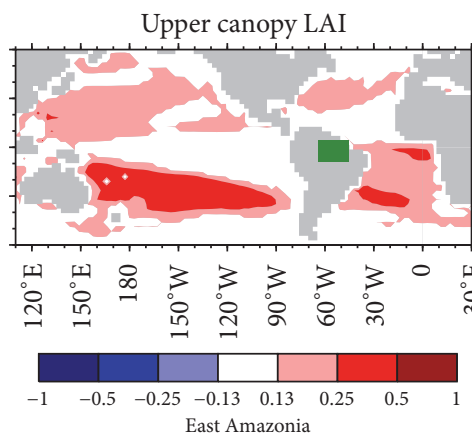

(g)

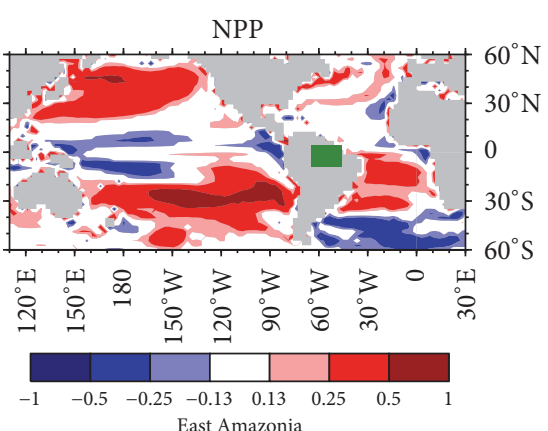

(b)

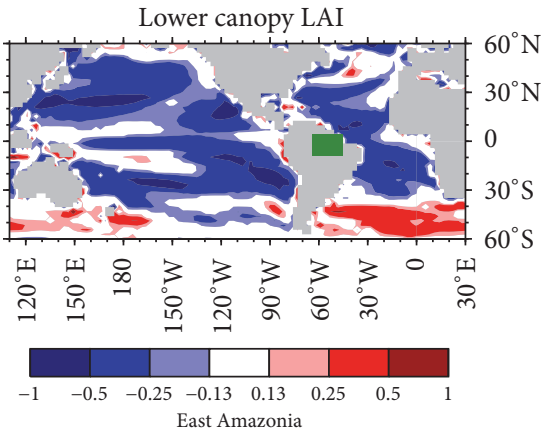

(d)

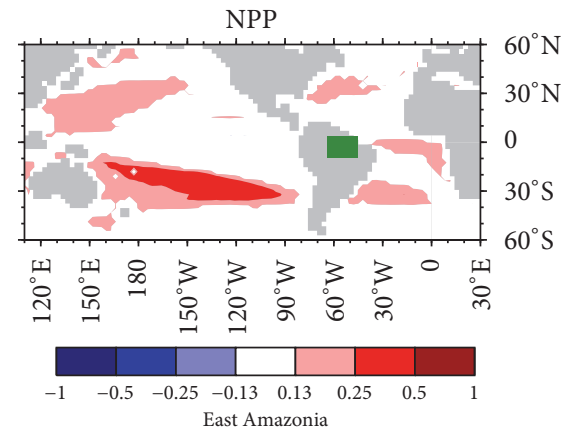

(f)

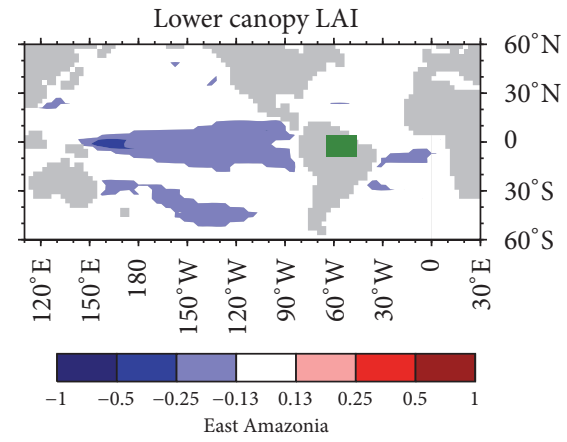

(h)

FIgURE 7: Same as Figure 5 but for EA region.

shows a similar pattern to that of the WA region (Figures 7(a)-7(c)). In contrast, lower canopy LAI shows a negative correlation (Figure 7(d)). Although the equatorial Pacific plays a significant role in defining the precipitation pattern in EA region, this is not reflected in NPP and upper canopy LAI, which are more influenced by the subtropical Pacific ocean. The tropical Atlantic ocean should, arguably, also be included as a driver of vegetation-climate interactions in the EA region, particularly for upper canopy LAI (Figure 7). 


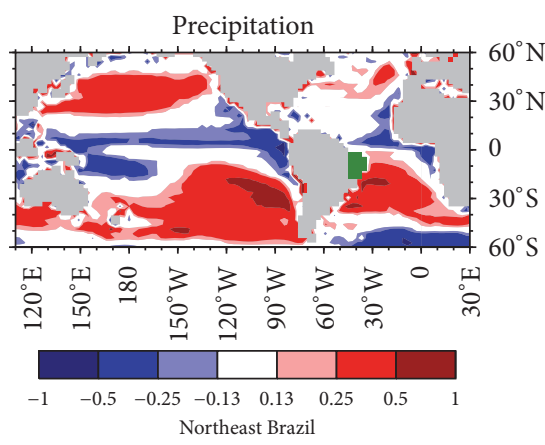

(a)

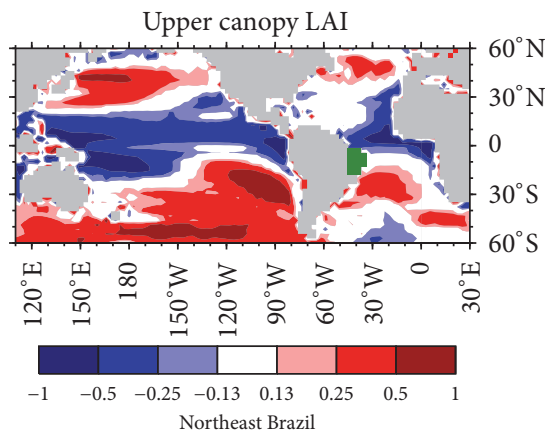

(c)

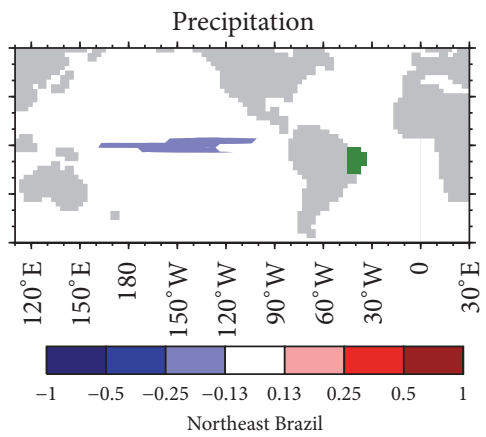

(e)

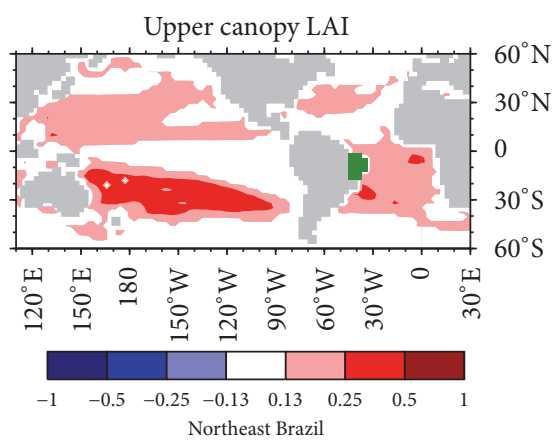

(g)

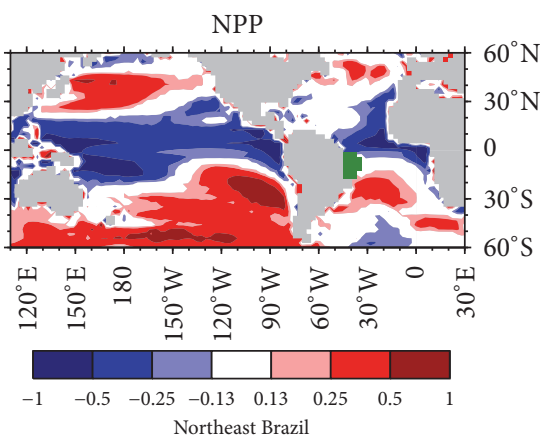

(b)

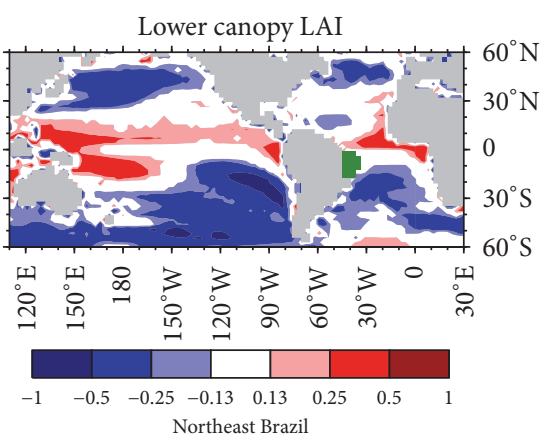

(d)

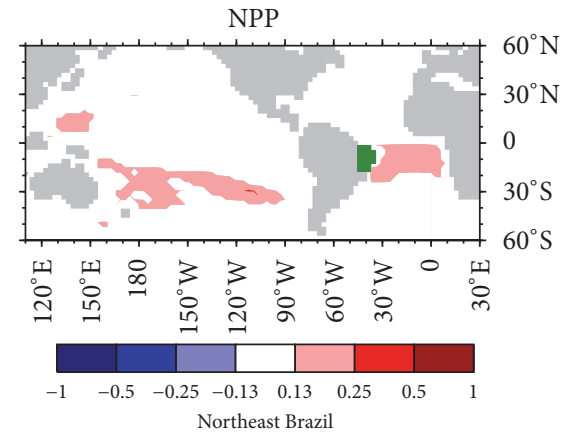

(f)

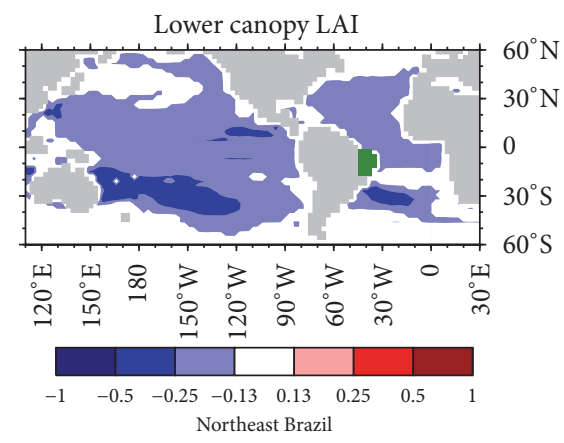

(h)

Figure 8: Same as Figure 5 but for NEB region.

The NEB region (Figure 8) is dominated by two biomes with distinct characteristics: the Atlantic forest is a region of tropical dry forest and tropical savanna. The second biome is the semiarid Caatinga, which extends into the interior of northeastern Brazil. This biome is characterized by xeric shrubland and sparse forests of small, thorny trees that change their leaves seasonally. There is a negative correlation between the equatorial Pacific SST and precipitation in the NEB region (Figure 8). This is expected, since there is an "atmospheric bridge" from the Pacific to the Atlantic 


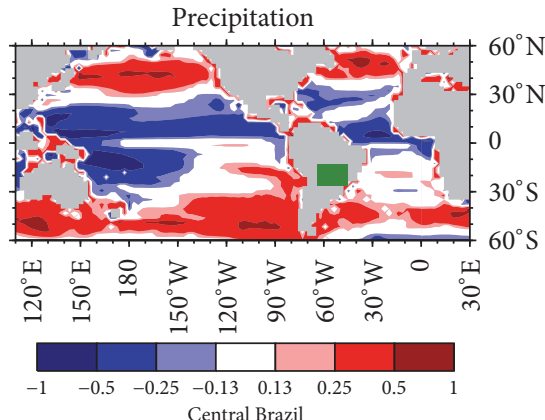

(a)

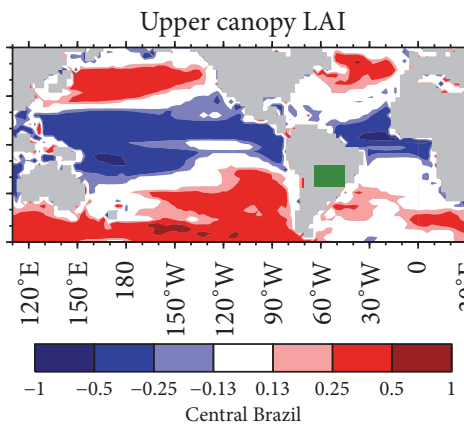

(c)

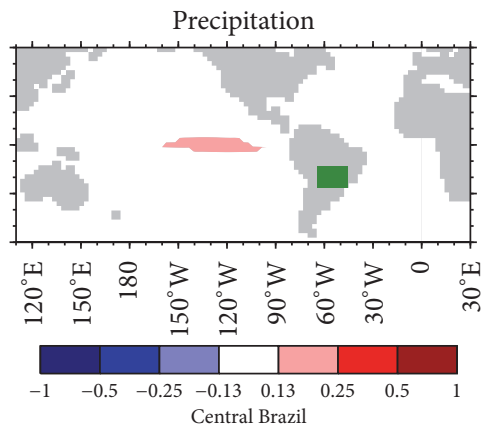

(e)

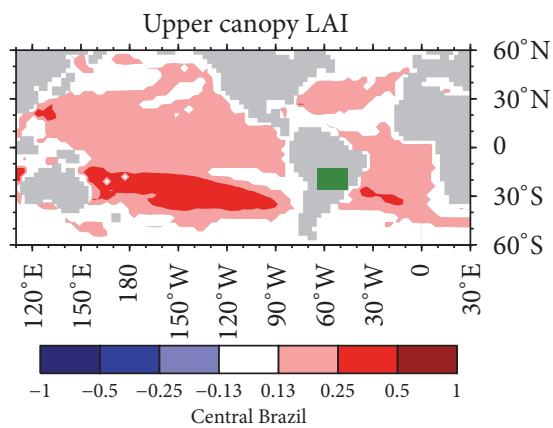

(g)

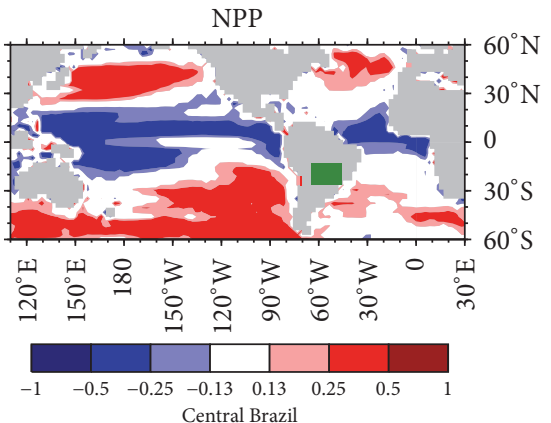

(b)

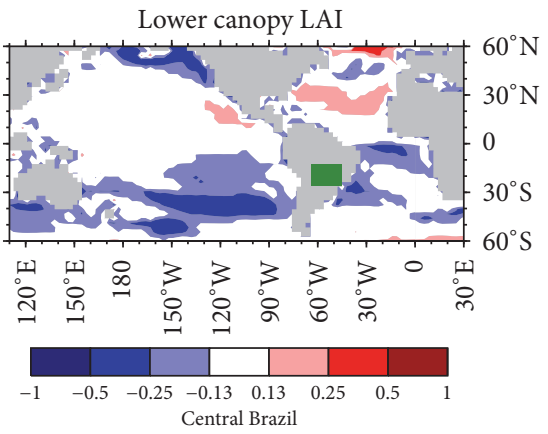

(d)

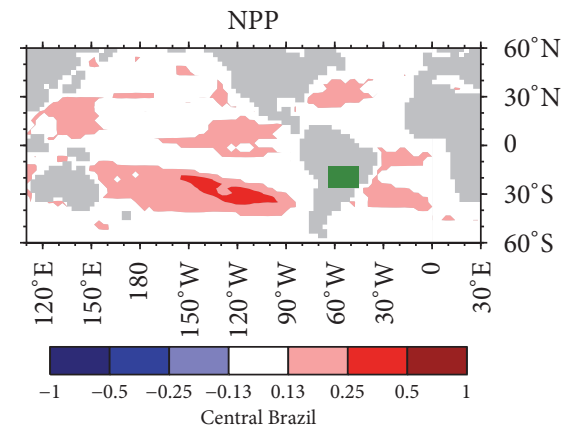

(f)

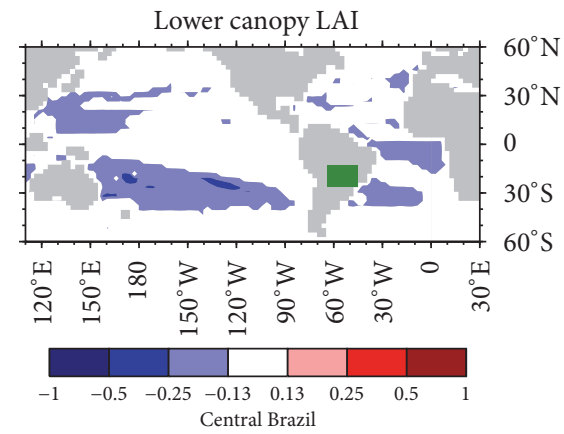

(h)

Figure 9: Same as Figure 5 but for CB region.

which consists of an upper-tropospheric wave train, entailing anomalous upper-tropospheric divergence and vertical motion over the tropical North Atlantic, which affects the surface meridional pressure profile and thus the North Atlantic tradewinds; the altered wind stress forcing modulates the
SST pattern and particularly the interhemispheric thermal gradient. This, in turn, controls the latitude position of the ITCZ and thus rainfall in the northeast of Brazil [39]. Conversely, positive correlations are characteristic of the subtropical Pacific and SH tropical Atlantic (Figure 8(a)). 


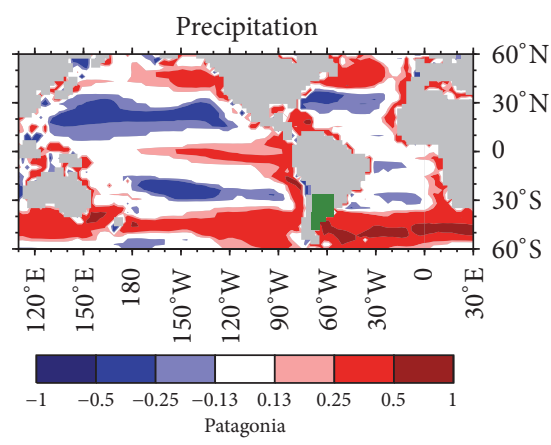

(a)

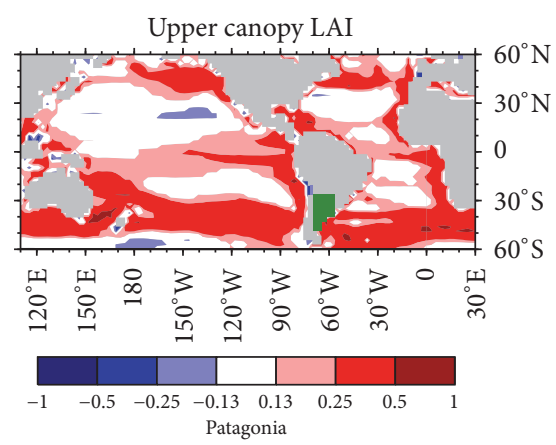

(c)

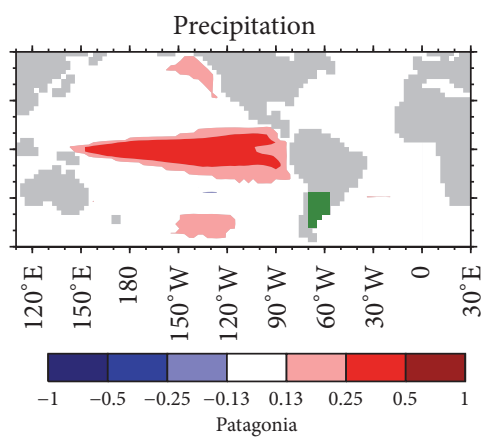

(e)

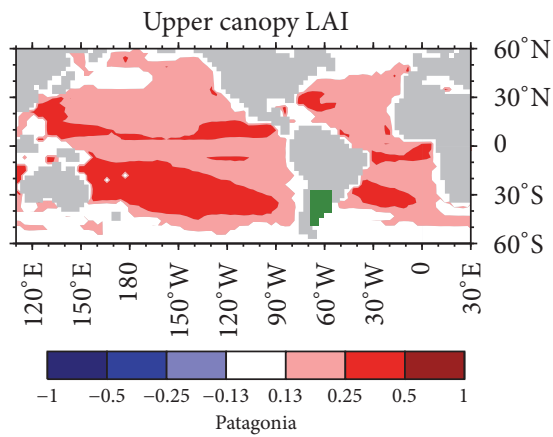

(g)

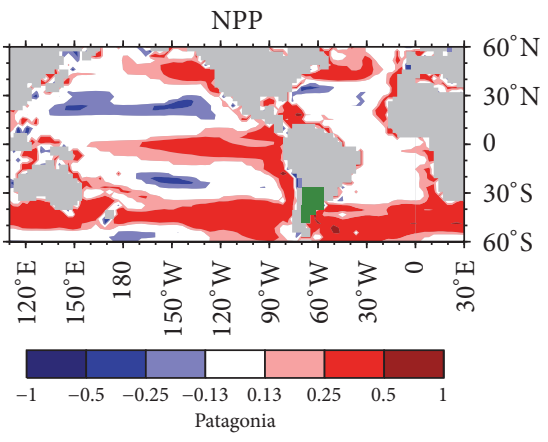

(b)

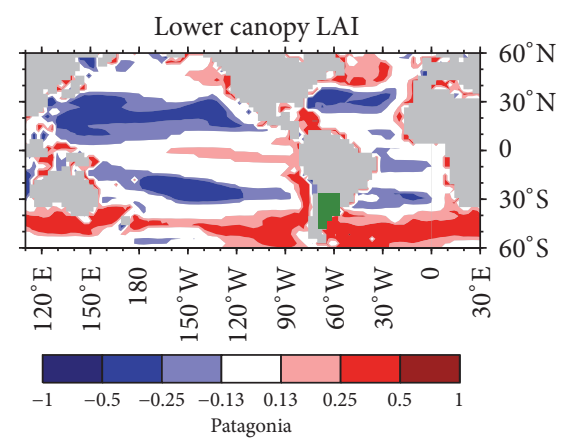

(d)

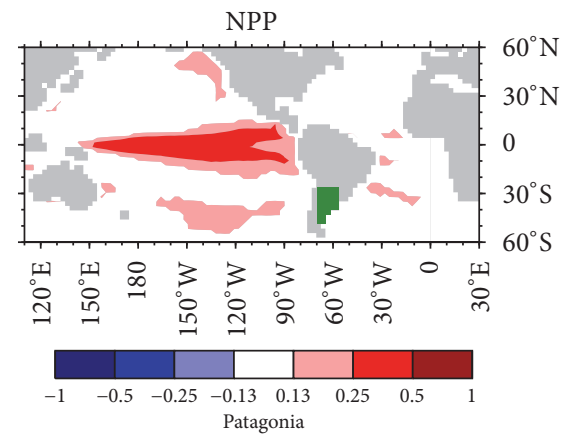

(f)

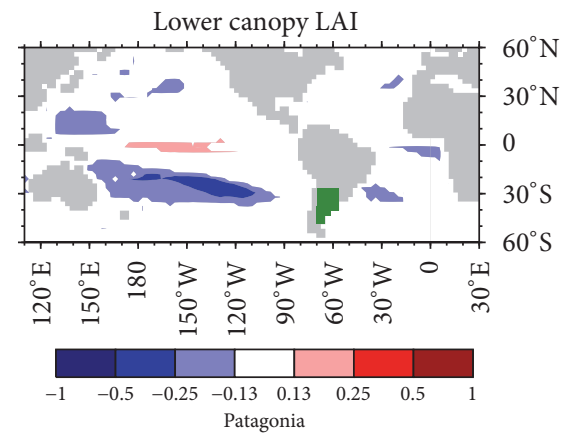

(h)

FIgURe 10: Same as Figure 5 but for PA region.

Positive SST anomalies in the tropical South Atlantic are associated with dominance of negative surface pressure anomalies and therefore with a southward migration of the ITCZ. As predicted, such migration may lead to positive precipitation anomalies. However, it should also be noted that the positive
SST anomalies in the tropical North Atlantic reinforce the austral displacement of the ITCZ, increasing the possibility of negative precipitation anomalies (Figure 8(a)). The results for NPP and upper canopy LAI are quite similar, with a negative trend in the tropical Pacific and tropical North Atlantic and 
a positive trend in extratropical oceans (Figures $8(\mathrm{~b})$ and 8(c)). Lower canopy LAI gives an inverse signal to that of precipitation, NPP, and upper canopy LAI (Figure $8(\mathrm{~d})$ ).

In the absence of global warming, precipitation in the NEB region shows a negative correlation with equatorial Pacific SSTs, which is directly related to the ENSO-when the SST is higher than normal there is a decrease in precipitation over the NEB region (Figure 8(e)). However, the equatorial Pacific does not cause substantial modifications in NPP and upper canopy LAI characteristics. NPP is positively correlated with subtropical South Pacific and tropical Atlantic SSTs (Figure 8(f)). Upper canopy LAI is correlated with positive values of SST anomalies in most parts of the ocean basins, particularly with the subtropical Pacific along the $30 \mathrm{~S}$ latitude belt (Figure $8(\mathrm{~g})$ ). Lower canopy LAI is negatively correlated with global SST (Figure $8(\mathrm{~h})$ ).

There is also a clear link between SST and vegetationclimate in the central part of South America, which is primarily dominated by savanna vegetation. Most noticeably, there are several similarities in the correlation distribution for precipitation, NPP, and upper canopy LAI (Figures 9(a)-9(c)). However, once again, these patterns do not match with those predicted for lower canopy LAI (Figure 9(d)). This is associated with the fact that the competition among PFTs is characterized by the ability of plants to capture resources, particularly the competition for common light and water resource pools.

For example, PFTs in the upper vegetation layer are able to capture light first and therefore shade the lower vegetation canopy [22]. When global warming is removed, precipitation in the $\mathrm{CB}$ region is positively correlated with equatorial Pacific SSTs, although the coefficients are low (Figure 9(e)). There was a positive correlation between NPP and SST in the tropical Pacific and the tropical Atlantic (Figure 9(f)). Upper canopy LAI is correlated with SST over most oceanic basins, with a higher index in the southern extratropical Pacific (Figure 9(g)). Lower canopy LAI is negatively correlated with subtropical South Pacific and Atlantic SSTs (Figure 9(h)).

The climate of the southern South America region (including Patagonia) is highly dependent on SST changes in the extratropics and is also correlated with the equatorial Pacific (Figure 10). The influence of extratropical SSTs may play a leading role in influencing precipitation, NPP, and both upper canopy LAI and lower canopy LAI. However, in the case of precipitation and lower canopy LAI, some response to the eastern subtropical northern Pacific is also observed. With no global warming, precipitation and NPP are strongly influenced by the equatorial Pacific, and upper canopy LAI is influenced by the global pattern of SST. Lower canopy LAI is mainly driven by the subtropical southern Pacific (Figure 10(h)).

\section{Conclusions}

We demonstrate the potential role of SST variations in the future dynamics of South American terrestrial ecosystems. In the first half of 21st century, our simulations predict an increase in vegetation productivity due to the effect of atmospheric $\mathrm{CO}_{2}$ fertilization. In general, increased atmospheric
$\mathrm{CO}_{2}$ emission is predicted to be accompanied by noticeable changes in regional vegetation composition and structure. $\mathrm{CO}_{2}$ enrichment is predicted to increase NPP in most South American ecosystems, with vegetation becoming denser through increases in upper canopy LAI, particularly in the Brazilian Cerrado region where the vegetation is predicted to be replaced by tropical deciduous forest. Moreover, the results of the "no warming" scenario indicate that SST patterns may influence the coupled atmosphere-biosphere system of all six South American regions.

Increased utilization of sophisticated and appropriately parameterized models (coupled vegetation-climate model) can provide a more realistic picture of the identity and relative importance of the main drivers of vegetation change under climate change. The results presented here strongly indicate the need for further investigation into the role of SST patterns on vegetation (and terrestrial ecosystems in general). Future research should focus on further elucidating the nature of complex ocean-atmosphere-biosphere interactions and their impacts on the macrogeographic distribution of vegetation and on climate variability.

\section{Disclosure}

The funding sources played no role in the study design, data collection, and analysis or in the writing or even in the decision to submit this manuscript for publication.

\section{Conflicts of Interest}

The authors declare that there are no conflicts of interest regarding the publication of this paper.

\section{Acknowledgments}

The authors acknowledge Amazonas and Minas Gerais State Research Funding Agencies (FAPEAM and FAPEMIG) for financial support. They also thank Dr. Richard J. Ladle for reviewing the English language and commenting on the manuscript.

\section{References}

[1] C. D. Thomas, A. Cameron, R. E. Green et al., "Extinction risk from climate change," Nature, vol. 427, no. 6970, pp. 145-148, 2004.

[2] R. J. Ladle, A. C. M. Malhado, and M. H. Costa, "Coupled atmosphere-biosphere models as a tool for conservation planning and policy," Brazilian Journal of Nature Conservation, vol. 9, no. 2, pp. 145-151, 2011.

[3] A. C. M. Malhado, R. J. Ladle, R. J. Whittaker, J. A. O. Neto, Y. S. Malhi, and H. ter Steege, "The ecological biogeography of Amazonia," Frontiers of Biogeography, 2013.

[4] S. Levis, J. A. Foley, and D. Pollard, "Large scale vegetation feedbacks on a doubled $\mathrm{CO}_{2}$ climate," Journal of Climate, vol. 13, no. 7, pp. 1313-1325, 2000.

[5] P. M. Cox, R. A. Betts, M. Collins, P. P. Harris, C. Huntingford, and C. D. Jones, "Amazonian forest dieback under climatecarbon cycle projections for the 21st century," Theoretical and Applied Climatology, vol. 78, no. 1-3, pp. 137-156, 2004. 
[6] R. A. Betts, P. M. Cox, M. Collins, P. P. Harris, C. Huntingford, and C. D. Jones, "The role of ecosystem-atmosphere interactions in simulated Amazonian precipitation decrease and forest dieback under global climate warming," Theoretical and Applied Climatology, vol. 78, no. 1-3, pp. 157-175, 2004.

[7] R. O'ishi and A. Abe-Ouchi, "Influence of dynamic vegetation on climate change arising from increasing $\mathrm{CO}_{2}$," Climate Dynamics, vol. 33, no. 5, pp. 645-663, 2009.

[8] F. Justino, A. S. de Mélo, A. Setzer et al., "Greenhouse gas induced changes in the fire risk in Brazil in $\mathrm{ECHAM}_{5} / \mathrm{MPI}-$ OM coupled climate model," Climatic Change, vol. 106, no. 2, pp. 285-302, 2011.

[9] F. Justino, F. Stordal, E. K. Vizy, K. H. Cook, and M. P. S. Pereira, "Greenhouse gas induced changes in the seasonal cycle of the Amazon Basin in coupled climate-vegetation regional model," Climate, vol. 4, no. 1, p. 3, 2016.

[10] J. A. Foley, S. Levis, M. H. Costa, W. Cramer, and D. Pollard, "Incorporating dynamic vegetation cover within global climate models," Ecological Applications, vol. 10, no. 6, pp. 1620-1632, 2000.

[11] P. M. Cox, R. A. Betts, C. D. Jones, S. A. Spall, and I. J. Totterdell, "Acceleration of global warming due to carbon-cycle feedbacks in a coupled climate model," Nature, vol. 408, no. 6809, pp. 184187,2000 .

[12] P. M. Cox, D. Pearson, B. B. Booth et al., "Sensitivity of tropical carbon to climate change constrained by carbon dioxide variability," Nature, vol. 494, no. 7437, pp. 341-344, 2013.

[13] P. Nobre and J. Shukla, "Variations of sea surface temperature, wind stress, and rainfall over the Tropical Atlantic and South America," Journal of Climate, vol. 9, no. 10, pp. 2464-2479, 1996.

[14] A. F. Diaz, C. D. Studzinski, and C. R. Mechoso, "Relationships between precipitation anomalies in Uruguay and Southern Brazil and sea surface temperature in the Pacific and Atlantic Oceans," Journal of Climate, vol. 11, no. 2, pp. 251-271, 1998.

[15] A. M. Grimm, V. R. Barros, and M. E. Doyle, "Climate variability in Southern South América associated with El Niño and La Niña events," Journal of Climate, vol. 13, pp. 35-58, 2000.

[16] M. R. Haylock, T. C. Peterson, L. M. Alves et al., "Trends in total and extreme South American rainfall in 1960-2000 and links with sea surface temperature," Journal of Climate, vol. 19, no. 8 , pp. 1490-1512, 2006.

[17] D. Jiang, Y. Zhang, and X. Lang, "Vegetation feedback under future global warming," Theoretical and Applied Climatology, vol. 106, no. 1-2, pp. 211-227, 2011.

[18] M. P. S. Pereira, A. C. M. Malhado, and M. H. Costa, "Predicting land cover changes in the Amazon rainforest: An oceanatmosphere-biosphere problem," Geophysical Research Letters, vol. 39, no. 9, Article ID L09713, 2012.

[19] J. T. Kiehl, J. J. Hack, G. B. Bonan, B. A. Boville, D. L. Williamson, and P. J. Rasch, "The National Center for Atmospheric Research Community Climate Model: CCM3," Journal of Climate, vol. 11, no. 6, pp. 1131-1149, 1998.

[20] G. J. Zhang and N. A. McFarlane, "Sensitivity of climate simulations to the parameterization of cumulus convection in the canadian climate centre general circulation model," Atmosphere - Ocean, vol. 33, no. 3, pp. 407-446, 1995.

[21] J. J. Hack, "Parameterization of moist convection in the National Center for Atmospheric Research community climate model (CCM2)," Journal of Geophysical Research, vol. 99, no. 3, pp. 5551-5568, 1994.
[22] J. A. Foley, I. C. Prentice, N. Ramankutty et al., "An integrated biosphere model of land surface processes, terrestrial carbon balance, and vegetation dynamics," Global Biogeochemical Cycles, vol. 10, no. 4, pp. 603-628, 1996.

[23] C. Delire, S. Levis, G. Bonan, J. Foley, M. Coe, and S. Vavrus, "Comparison of the climate simulated by the CCM3 coupled to two different land-surface models," Climate Dynamics, vol. 19, no. 8, pp. 657-670, 2002.

[24] C. J. Kucharik, J. A. Foley, C. Délire et al., “Testing the performance of a dynamic global ecosystem model: water balance, carbon balance, and vegetation structure," Global Biogeochemical Cycles, vol. 14, no. 3, pp. 795-825, 2000.

[25] M. C. A. Senna, M. H. Costa, E. A. Davidson, and C. A. Nobre, "Modeling the impact of net primary production dynamics on post-disturbance Amazon savannization," Anais da Academia Brasileira de Ciencias, vol. 86, no. 2, pp. 621-632, 2014.

[26] M. C. A. Senna, M. H. Costa, L. I. Chipponelli Pinto, H. M. Acioli Imbuzeiro, L. M. Freitas Diniz, and G. F. Pires, "Challenges to reproduce vegetation structure and dynamics in Amazonia using a coupled climate-biosphere model," Earth Interactions, vol. 13, pp. 1-28, 2009.

[27] M. P. S. Pereira, F. Justino, A. C. M. Malhado, H. Barbosa, and J. Marengo, "The influence of oceanic basins on drought and ecosystem dynamics in Northeast Brazil," Environmental Research Letters, vol. 9, no. 12, Article ID 124013, 2014.

[28] M. New, M. Hulme, and P. Jones, "Representing twentiethcentury space-time climate variability. Part I. Development of a 1961-90 mean monthly terrestrial climatology," Journal of Climate, vol. 12, no. 2-3, pp. 829-856, 1999.

[29] C. J. Willmott and K. Matsuura, Terrestrial Air Temperature And Precipitation: Monthly and Annual Time Series (1950-1999), Center for Climate Research, version 1.02 edition, 2001.

[30] P. Xie and P. A. Arkin, "Global precipitation: a 17-year monthly analysis based on gauge observations, satellite estimates, and numerical model outputs," American Meteorological Society, vol. 78, pp. 2539-2558, 1997.

[31] G. J. Huffman, R. F. Adler, and P. Arkin, "The global precipitation climatology project (GPCP) combined precipitation dataset," Bulletin of the American Meteorological Society, vol. 78, no. 1, pp. 5-20, 1997.

[32] E. Kalnay, M. Kanamitsu, R. Kistler et al., "The NCEP/NCAR 40-year reanalysis project," Bulletin of the American Meteorological Society, vol. 77, no. 3, pp. 437-471, 1996.

[33] S. M. Uppala, P. W. allberg, A. J. Simmons, U. Andrae, and V. da Costa Bechtold, “The ERA-40 re-analysis," Quarterly Journal of the Royal Meteorological Society, vol. 131, pp. 2961-3012, 2005.

[34] P. Aceituno, M. D. R. Prieto, M. E. Solari, A. Martínez, G. Poveda, and M. Falvey, “The 1877-1878 El Niño episode: Associated impacts in South America," Climatic Change, vol. 92, no. 3-4, pp. 389-416, 2009.

[35] J. J. Barsugli, S.-I. Shin, and P. D. Sardeshmukh, "Sensitivity of global warming to the pattern of tropical ocean warming," Climate Dynamics, vol. 27, no. 5, pp. 483-492, 2006.

[36] J. A. Marengo, C. A. Nobre, J. Tomasella et al., “The drought of Amazonia in 2005," Journal of Climate, vol. 21, no. 3, pp. 495516, 2008.

[37] R. G. Wagner, "Decadal-scale trends in mechanisms controlling meridional sea surface temperature gradients in the tropical Atlantic," Journal of Geophysical Research: Oceans, vol. 101, no. C7, pp. 16683-16694, 1996. 
[38] Y. Zhang, M. W. John, and S. B. David, "ENSO-like interdecadal variability: 1900-93," Journal of Climate, vol. 10, no. 5, pp. 10041020, 1997.

[39] S. Hastenrath, "Circulation and teleconnection mechanisms of Northeast Brazil droughts," Progress in Oceanography, vol. 70, no. 2-4, pp. 407-415, 2006.

[40] J. F. Scinocca, N. A. McFarlane, M. Lazare, J. Li, and D. Plummer, "The CCCma third generation AGCM and its extension into the middle atmosphere," Atmospheric Chemistry and Physics, vol. 8, no. 22, pp. 7055-7074, 2008.

[41] D. Salas-Mélia, F. Chauvin, M. Déqué et al., "Description and validation of the CNRM-CM3 global coupled model," CNRM 103, 2005.

[42] H. B. Gordon, L. D. Rotstayn, J. L. McGregor et al., "The CSIRO Mk3 Climate System Model," CSIRO Atmospheric Research Technical, 2002.

[43] T. L. Delworth, A. J. Broccoli, A. Rosati et al., "GFDL's CM2 global coupled climate models. Part I: formulation and simulation characteristics," Journal of Climate, vol. 19, no. 5, pp. 643674, 2006.

[44] G. A. Schmidt, R. Ruedy, and J. E. Hansen, "Present-day atmospheric simulations using GISS ModelE: comparison to in situ, satellite, and reanalysis data," Journal of Climate, vol. 19, no. 2, pp. 153-192, 2006.

[45] O. Marti, P. Braconnot, J. Bellier et al., "The new IPSL climate system model: IPSLCM4," Note du Pôle de Modélisation, vol. 26, pp. 1288-1619, 2005.

[46] H. Hasumi and S. Emori, "K-1 Coupled GCM (MIROC) Description,” Tech. Rep. 1, Center for Climate System Research, Kashiwa, Japan, 2004.

[47] J. H. Jungclaus, N. Keenlyside, M. Botzet et al., "Ocean circulation and tropical variability in the coupled model ECHAM5/ MPI-OM," Journal of Climate, vol. 19, no. 16, pp. 3952-3972, 2006.

[48] W. D. Collins, C. M. Bitz, M. L. Blackmon, . et al., "The community climate system model version 3 (CCSM3)," Journal of Climate, vol. 19, no. 11, pp. 2122-2143, 2006.

[49] C. Gordon, C. Cooper, C. A. Senior et al., "The simulation of SST, sea ice extents and ocean heat transports in a version of the Hadley centre coupled model without flux adjustments," Climate Dynamics, vol. 16, no. 2-3, pp. 147-168, 2000. 

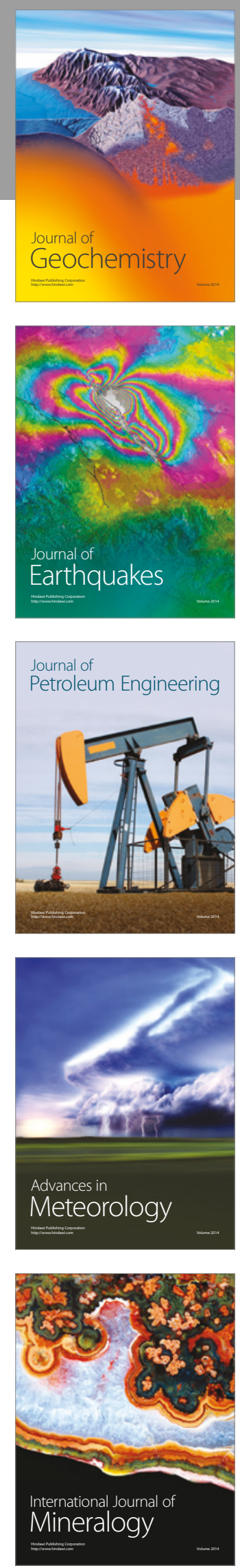
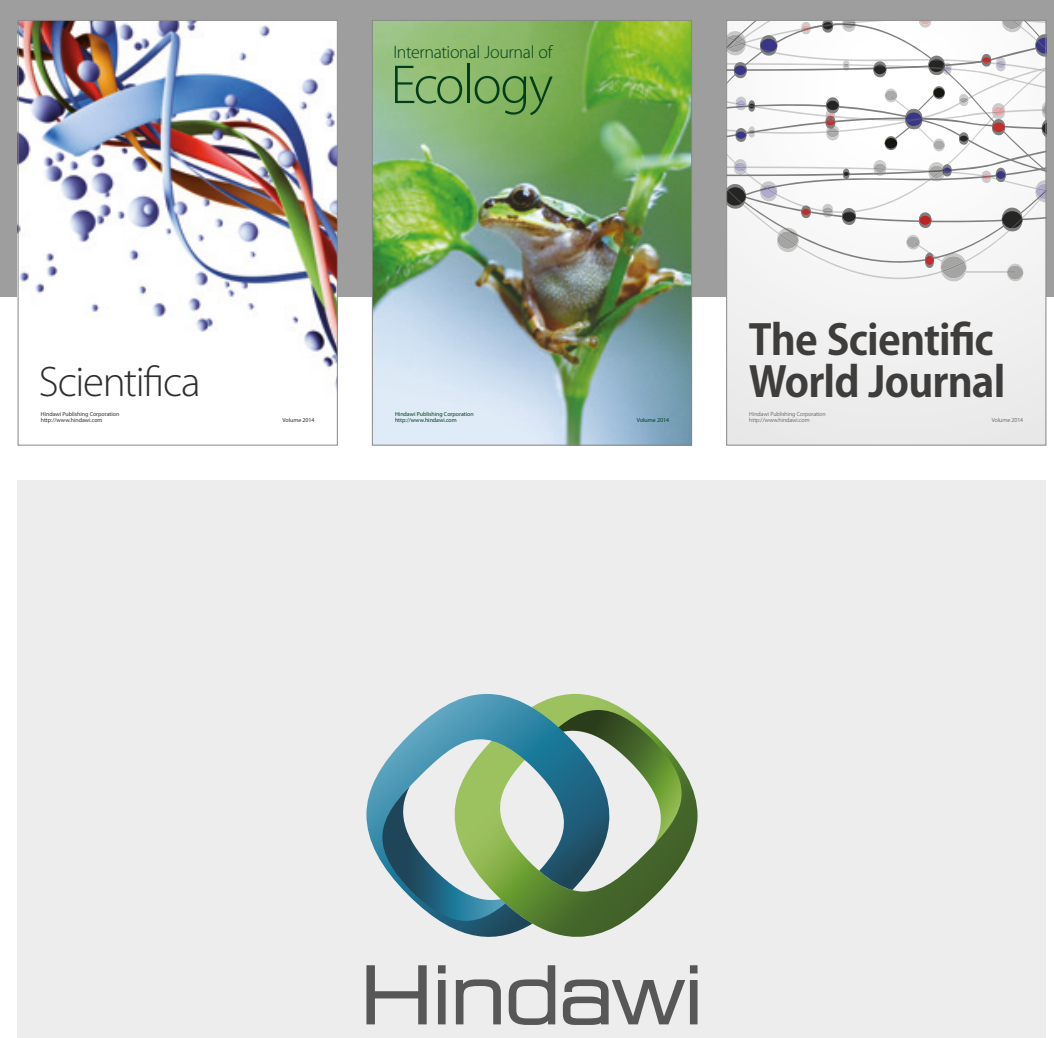

Submit your manuscripts at

https://www.hindawi.com
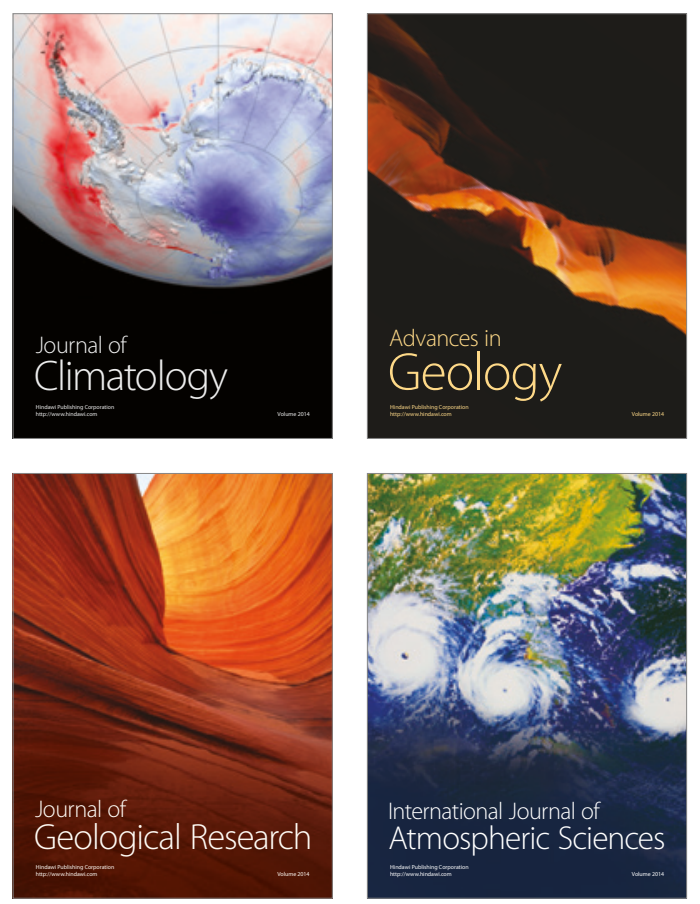

The Scientific

World Journal
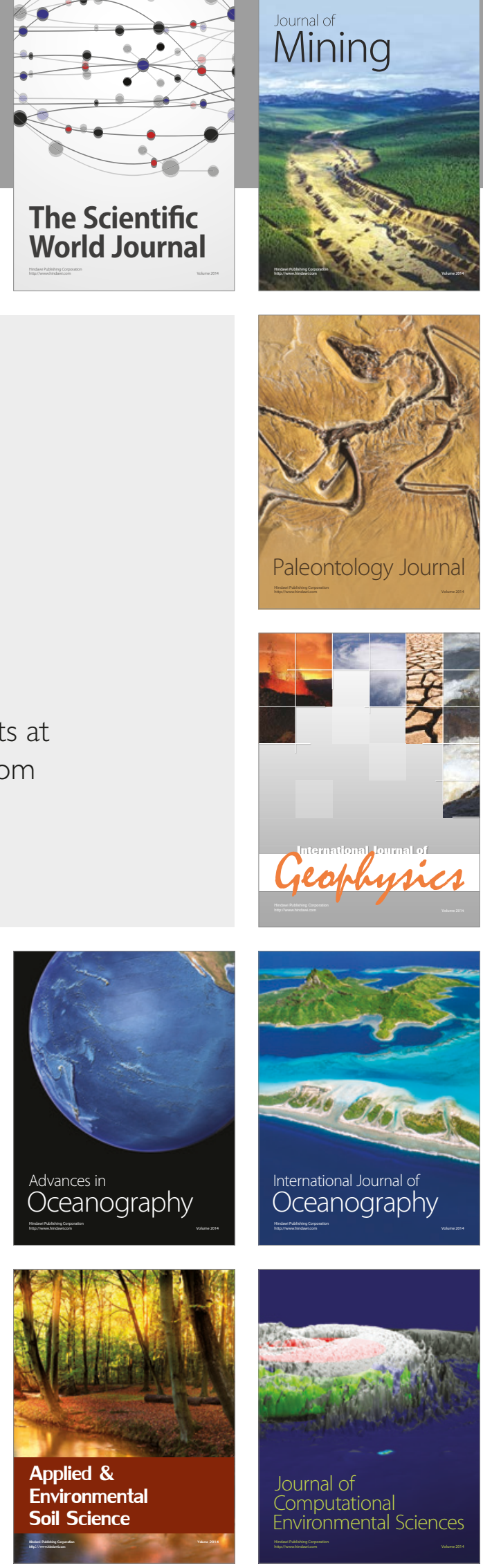